\title{
PROHIBICIÓN DE DISCRIMINACIÓN Y RELACIONES ENTRE PARTICULARES
}

\author{
JUAN MARÍA BILBAO UBILLOS \\ Profesor Titular de Derecho Constitucional \\ Universidad de Valladolid
}

SUMARIO

I. Prohibición de discriminación y relaciones regidas por el derecho privado: claves para un enfoque constitucionalmente adecuado.

II. La proyección en el ámbito civil.

III. La prohibición de discriminación en el acceso a los establecimientos abiertos al público.

IV. Prohibición de discriminación y autonomía asociativa.

\section{PROHIBICIÓN DE DISCRIMINACIÓN Y RELACIONES REGIDAS POR EL DERECHO PRIVADO: CLAVES PARA UN ENFOQUE CONSTITUCIONALMENTE ADECUADO}

\section{I.1. El PRINCIPIO DE IGUALDAD}

El art. 14 de la Constitución española contiene, por un lado, una cláusula general de igualdad, y por otro, un mandato tajante de no discriminación por razones específicas: "Los españoles son iguales ante la ley, sin que pueda prevalecer discriminación alguna por razón de nacimiento, raza, sexo, religión, opinión o cualquier otra condición o circunstancia personal o sociab. Es indudable que el principio general de igualdad "es un principio básico de nuestro ordenamiento jurídico en todas sus ramas" (STC 38/1986, de 21 de marzo) y como tal vincula al legislador (en cualquier sector del ordenamiento) y a quienes ejercen la potestad reglamentaria. Este principio constitucional opera, ade- 
más, directamente, como criterio de valoración de la licitud de la actuación de los poderes públicos. La cuestión es si su vigencia se extiende ex Constitutione, sin necesidad de una previa mediación legislativa, al ámbito de las decisiones o normas emanadas de la voluntad de uno o varios sujetos privados. En otras palabras, si puede concebirse como un principio regulador de las relaciones sociales que podría invocar cualquier afectado por comportamientos supuestamente arbitrarios de un particular o una entidad privada.

La autorizada respuesta del Tribunal Constitucional a este interrogante se puede resumir en la siguiente fórmula: como regla general, la Constitución no impone en las relaciones entre particulares la igualdad de trato, porque en esa esfera es la autonomía privada, como expresión de la libertad personal, el valor que primordialmente hay que proteger ${ }^{1}$. Esa regla (el principio de igualdad en su dimensión positiva de derecho a un tratamiento igual sólo vincula a los poderes públicos) admite algunas excepciones en el campo de las relaciones laborales, un terreno en el que la presencia del interés público es mayor. Por eso, el Tribunal no ha dudado a la hora de anular determinadas cláusulas incluidas en convenios colectivos por considerarlas incompatibles con el art. $14 \mathrm{CE}^{2}$.

Vemos, pues, cómo el imperativo constitucional de igualdad tiene una eficacia muy limitada en el ámbito de las relaciones regidas por el Derecho privado, debido al amplio juego que en este contexto se reconoce al principio de autonomía de la voluntad, un principio que cuenta también con respaldo constitucional (arts. 1.1, 10.1, 38, entre otros) y en cuya virtud las partes implicadas son libres para gestionar sus propios intereses y regular sus relaciones, sin injerencias externas, dentro siempre de los límites que marca el art. 1255 del CC $^{3}$.

1 Eso es lo que sostiene, por ejemplo, SUAY RINCON, J.: «El principio de igualdad en la jurisprudencia del Tribunal Constitucional", en Estudios sobre la Constitución Española. Homenaje al profesor E. García de Enterría, Tomo II, Madrid, Civitas, 1991, p. 853.

2 La sujeción de los convenios colectivos al principio constitucional de igualdad, que adquiere en este ámbito "perfiles propios" (STC 171/1989, de 19 de octubre), ha sido reafirmada expresamente por el Tribunal Constitucional mediante declaraciones inequívocas, como la contenida en la STC 177/1993, de 31 de mayo: no cabe establecer en tales convenios "diferencias de trato arbitrarias e irrazonables entre situaciones iguales o equiparables, y muy especialmente, en caso de identidad de trabajo". Pero no es la única excepción: hay otros escenarios en los que no puede excluirse a priori la operatividad inmediata. Es el caso de la gestión de servicios públicos por particulares o empresas privadas mediante la correspondiente concesión administrativa. En estos supuestos, la prestación del servicio se somete a un régimen especial controlado por la Administración que incluye la exigencia de todos los usuarios reciban el mismo trato, con exclusión de cualquier tipo de discriminación en el acceso, en las tarifas o en las condiciones de prestación del servicio. Otra hipótesis en la que podría sostenerse la existencia de un deber de tratamiento igual es la de aquellos individuos u organizaciones que disfrutan de ayudas o ventajas públicas. Un centro docente concertado, que se financia con fondos públicos, no puede aplicar criterios discriminatorios a la hora de seleccionar su alumnado.

3 El principio de igualdad no tiene en este contexto el mismo alcance que en el marco de las relaciones entre ciudadano y Estado. Por la sencilla razón de que "en el ámbito de las relaciones privadas... los derechos fundamentales y, entre ellos, el principio de igualdad, han de aplicarse matizadamente, pues han de hacerse compatibles con otros valores o parámetros que tienen su último origen en el principio de la autonomía de la voluntad, y que se manifiestan a través de los derechos y deberes que nacen de la relación contractual. (STC 177/1988, de 10 de octubre). La obli- 
Y ello porque, como ha explicado R. Bercovitz, "es inherente al propio concepto de autonomía privada el predominio de la voluntad individual sobre la igualdad: se contrata con quien se quiera y como se quiera, se dispone en testamento a favor de quien uno quiera y como se quiera, se dona a quien se quiera y como se quiera,... se ejercen los derechos frente a quien uno quiera ${ }^{4}$.

En líneas generales, la doctrina rechaza la vigencia del principio de igualdad en la esfera de las relaciones privadas en cuanto prohibición de la arbitrariedad o imperativo de razonabilidad en el comportamiento del particular ${ }^{5}$. La libertad individual (en su vertiente negocial o asociativa) incluye necesariamente un margen de arbitrio y no puede limitarse injustificadamente. Puede ejercerse de forma irracional o incongruente. L. Henkin, un autor norteamericano, defendió hace muchos años "the individual's freedom to be irrational, una libertad que la Constitución nunca ha pretendido eliminar. En lugar de imponer rígidamente a cada individuo que trate a los demás con exquisita igualdad en sus relaciones recíprocas, obligándole a justificar de forma objetiva cualquier desviación de esa regla (su decisión, por ejemplo, de no contratar con una persona cuando lo ha hecho con otras en idénticas circunstancias), se debe permitir un espacio de espontaneidad y hasta de arbitrariedad ${ }^{6}$. Porque existe una esfera de actuación puramente privada, un reducto de vida auténticamente privada, que queda fuera del alcance de las normas constitucionales,

gación de respetar el principio constitucional de igualdad ante la ley, dice el Tribunal en la Sentencia 108/1989, de 8 de junio, "se impone a los órganos del poder público, pero no a los sujetos privados, cuya autonomía está limitada sólo por la probibición de incurrir en discriminaciones contrarias al orden público constitucional. Fuera de estos supuestos, una situación de desigualdad de hecho, no imputable a una norma, sólo tendrá relevancia jurídica si se demuestra que existe, en la Constitución o en una norma de rango inferior, un principio jurídico del que deriva la necesidad de igualdad de trato entre los desigualmente tratados (SSTC 59/1982, de 28 de julio, y 34/1984, de 9 de marzo, entre otras).

4 BERCOVITZ, R.: "Principio de igualdad y Derecho privado", Anuario de Derecho Civil, n. ${ }^{\circ} 2$, 1990, pp. 424-425. Para este autor, el art. 14 CE prohíbe, como parte del orden público, que el ejercicio de la autonomía privada produzca discriminaciones manifiestas por alguno de los motivos expresamente previstos en el citado precepto. El problema, según ALFARO, J. ("Autonomía privada y derechos fundamentales", Anuario de Derecho Civil, tomo XLVI, Fasc. 1, 1993, pp. 78, 95-96 y 113114) debería plantearse bajo otra perspectiva: la de la protección de la dignidad humana por parte del Estado. En esta misma línea, CARRASCO, A. («El principio de no discriminación por razón de sexo", Revista Jurídica de Castilla-La Mancha, n. 11-12, 1991, p.10-14) ha sostenido que el valor igualdad no constituye "un fin último en el tráfico privado" y no puede ser, por tanto, la referencia última del juicio de ilicitud. En su opinión, las diferencias de trato que tienen su origen en decisiones tomadas por sujetos privados no son ilícitas en sí mismas. Solo se calificarán como tales aquellas que, por su trascendencia social u otras razones, impliquen además una violación de otros valores constitucionales sustantivos (la libertad o la dignidad de una de las partes, por ejemplo).

5 Un resumen de las diversas aportaciones doctrinales puede verse en BILBAO UBILLOS, J.M.: La eficacia de los derechos fundamentales frente a particulares. Análisis de la jurisprudencia del Tribunal Constitucional, Madrid, BOE/CEPC, 1997, pp. 360-380 y 395-436) y BILBAO UBILLOS, J. M./REY MARTINEZ, F.: "Veinte años de jurisprudencia sobre la igualdad constitucional", en $L a$ Constitución y la práctica del Derecho (dir. por Aragón Reyes, M. y Martínez-Simancas, J.), tomo I, Madrid, Aranzadi/BCH, 1998, pp. 243-339.

6 VIEIRA DE ANDRADE, J. C.: Os direitos fundamentais na Constituçao portuguesa de 1976, Coimbra, Livraria Almedina, 1987, pp. 296 y ss. 
en el que los individuos son libres de discriminar a la hora de seleccionar las personas con las que van a relacionarse (pueden invitar a su casa o a una fiesta a quien crean conveniente, asociarse con quienes deseen y negarse a entrar en un determinado establecimiento, por los motivos que sean), libres de regular esas relaciones (determinando el contenido de los contratos, de los estatutos sociales o de las disposiciones testamentarias) y de comportarse, en general, de una manera que le está vedada al Estado.

Ni siquiera los que abogan por la máxima eficacia de los preceptos constitucionales niegan que esas áreas de inmunidad o autonomía existen ${ }^{7}$. Al fin y al cabo, la abolición de esa esfera privada es una de las señas de identidad del totalitarismo. La existencia de estas válvulas de escape, de esos espacios de vida privada en los que uno actúa sin tener que dar explicaciones, marca la diferencia entre una sociedad libre y una sociedad ocupada por el Estado ${ }^{8}$. Extender al ámbito de las relaciones jurídico-privadas el principio constitucional de igualdad, una regla ajena a este mundo, puede acarrear consecuencias absurdas e insoportables. ¿Puede un inquilino oponerse al desahucio por falta de pago de la renta alegando el hecho de que el arrendador no ha desalojado a otro inquilino en las mismas circunstancias??

De acuerdo con este planteamiento, el principio constitucional de igualdad no operaría directamente como límite de la autonomía de la voluntad en el Derecho privado. La vinculación al principio de igualdad sólo puede imponerse de forma mediata, por vía legislativa, como sucede en el ámbito laboral, en la normativa reguladora de las asociaciones o en los procedimientos concursales.

7 Véase, por ejemplo, en la doctrina brasileña SARMENTO, D.: Direitos fundamentais e relaçoes privadas, Edit. Lumen Juris, Rio de Janeiro, 2004, pp. 372-373.

8 He defendido en varios trabajos la vigencia de los derechos fundamentales en las relaciones entre particulares. No soy sospechoso en ese sentido. Pero lo he hecho siempre con matices: en función de los derechos en liza, del tipo de relación, de la presencia o no de un poder privado. Esa vigencia no puede afirmarse a costa de la autonomía privada. Es evidente, por ejemplo, que las cargas familiares y las labores domésticas están muy mal repartidas, pero la solución no está en colocar un inspector en cada hogar para que vigile y sancione.

9 Ante una demanda de amparo bastante disparatada, promovida por un vecino que se sentía discriminado por la actitud hostil de los propietarios de la vivienda inmediatamente superior a la suya, que habían denunciado al recurrente por el cerramiento ilegal de su terraza, cuando era público y notorio que en otro piso de la misma planta se había efectuado el cerramiento sin que aquéllos reaccionaran, el Tribunal Constitucional, que decretó la inadmisión del recurso mediante el Auto 1069/1987, de 30 de septiembre, aprovechó la ocasión para hacer una atinada observación: "Ningún precepto, ni constitucional ni ordinario (salvo, en ocasiones, el principio de buena fe del art. 7 del CC...) obliga a una persona a ejercitar sus derechos subjetivos o sus acciones en forma idéntica frente a sujetos pasivos diferentes, sin que, fuera de los mencionados casos de buena fe o abuso de derecho, se puedan medir los móviles que a tal actuación impulse. Es claro, por ejemplo, que un acreedor puede ser enérgico frente a un deudor y no serlo frente a otro, o reclamar prontamente la deuda a uno y condonarla total o parcialmente a otro. Serían legítimas, por tanto, las diferencias de trato fundadas en motivos distintos a los mencionados en el art. 14 (la preferencia por los matrimonios sin hijos manifestada por el propietario de una vivienda a la hora de alquilarla, por ejemplo). Y es que el ejercicio legítimo de la libertad contractual comporta normalmente una elección: uno decide contratar con alguien, con exclusión de los demás. Y no es necesario justificar racionalmente esa preferencia. 
Y siempre con prudencia, para no aniquilar la especificidad de este tipo de relaciones.

Dos ejemplos recientes de políticas de igualdad impulsadas por el legislador son la Ley 13/2005, de 1 de julio, por la que se modificó el Código Civil en materia de derecho a contraer matrimonio ${ }^{10}$ y el Proyecto de Ley Orgánica de igualdad entre mujeres y hombres remitido por el Gobierno a las Cortes Generales en julio de 2006. En la Exposición de Motivos se recuerda que la igualdad entre mujeres y hombres es un principio jurídico universal reconocido en diversos textos internacionales y también un principio fundamental en la Unión Europea ${ }^{11}$. Se afirma que el pleno reconocimiento de la igualdad formal ante la ley no es suficiente. La violencia de género, la discriminación salarial, el mayor desempleo femenino, o la todavía escasa presencia de las mujeres en puestos de responsabilidad política, social y económica muestran cómo la igualdad plena, efectiva, entre mujeres y hombres es todavía hoy una tarea pendiente que precisa de nuevos instrumentos jurídicos.

Es preciso combatir todas las manifestaciones aún subsistentes de discriminación, directa o indirecta, por razón de sexo y promover la igualdad real entre mujeres y hombres, con remoción de los obstáculos y estereotipos sociales que impiden alcanzarla. Y eso "implica necesariamente una proyección de este principio sobre los diversos ámbitos del ordenamiento y de la realidad social en que pueda generarse o perpetuarse la discriminación.

Por ese motivo, el proyecto no se ocupa sólo de las políticas públicas, una opción que se justifica así en la Exposición de Motivos: "el logro de la igualdad en nuestra sociedad requiere no sólo del compromiso de los sujetos públicos, sino también de su promoción decidida en la órbita de las relaciones entre

10 La Historia, se dice en la Exposición de Motivos de esta Ley, "evidencia una larga trayectoria de discriminación basada en la orientación sexual, discriminación que el legislador ha decidido remover. El establecimiento de un marco de realización personal que permita que aquellos que libremente adoptan una opción sexual y afectiva por personas de su mismo sexo puedan desarrollar su personalidad y sus derechos en condiciones de igualdad se ha convertido en exigencia de los ciudadanos de nuestro tiempo, una exigencia a la que esta ley trata de dar respuesta. Mediante la adición de un segundo párrafo en el art. 44 CC (El matrimonio tendrá los mismos requisitos y efectos cuando ambos contrayentes sean del mismo o de diferente sexo) la ley permite que el matrimonio sea celebrado entre personas del mismo o distinto sexo, con plenitud e igualdad de derechos y obligaciones (incluida la posibilidad de ser parte en procedimientos de adopción). Por otra parte, en los distintos artículos del Código Civil relativos al matrimonio, las referencias al marido y a la mujer se sustituyen por la mención a los cónyuges o a los consortes.

11 Desde la entrada en vigor del Tratado de Ámsterdam, en 1999, la igualdad entre mujeres y hombres es un objetivo que debe integrarse en todas las políticas y acciones de la Unión y de sus miembros. Con amparo en el antiguo artículo 111 del Tratado de Roma, se ha desarrollado un acervo comunitario sobre igualdad de sexos de gran amplitud e importante calado, a cuya adecuada transposición se dirige, en buena medida, la presente Ley. En particular, esta Ley incorpora al ordenamiento español las dos últimas Directivas en materia de igualdad de trato, la 2002/73/CE, de reforma de la Directiva 76/207/CEE, relativa a la aplicación del principio de igualdad de trato entre hombres y mujeres en lo que se refiere al acceso al empleo, a la formación y a la promoción profesionales, y a las condiciones de trabajo; y la Directiva 2004/113/CE, sobre aplicación del principio de igualdad de trato entre hombres y mujeres en el acceso a bienes y servicios y su suministro. 
particulares ${ }^{12}$. De ahí que la Ley regule el acceso a bienes y servicios, tratando de conjugar los principios de libertad y autonomía contractual con el fomento de la igualdad de trato entre mujeres y hombres ${ }^{13}$. Se prevén asimismo medidas de promoción de la igualdad efectiva en las empresas privadas, como las que se recogen en materia de contratación (preferencia en la adjudicación de contratos por parte de las Administraciones Públicas) o en relación con los consejos de administración ${ }^{14}$.

Como era de esperar, el proyecto presta una especial atención a la corrección de las desigualdades en el ámbito de las relaciones laborales. Se reconoce el derecho a la conciliación de la vida personal, familiar y laboral y se promueve la adopción de medidas concretas a favor de la igualdad (de acción positiva incluso) en el marco de la negociación colectiva. Se establece, en concreto, la obligación de negociar planes de igualdad en las empresas de más de 250 trabajadores. La propia Ley incorpora algunas medidas para garantizar la igualdad de trato y de oportunidades entre mujeres y hombres en el acceso al empleo, en la formación y promoción profesionales, y en las condiciones de trabajo (incluidas las retributivas) ${ }^{15}$. Entre ellas, la modificación del Estatuto de

12 Basta leer el artículo 1, que define el objeto de la Ley en los siguientes términos: "1. Esta Ley tiene por objeto hacer efectivo el principio de igualdad de trato y de oportunidades entre mujeres y hombres, en particular mediante la eliminación de la discriminación de la mujer, sea cual fuere su circunstancia o condición, y en cualesquiera de los ámbitos de la vida y, singularmente, en las esferas politica, civil, laboral, económica, social y cultural... 2. A estos efectos, la Ley establece principios de actuación de los Poderes Públicos, regula derechos y deberes de las personas fisicas y jurídicas, tanto públicas como privadas, y prevé medidas destinadas a eliminar y corregir en los sectores público y privado, toda forma de discriminación por razón de sexo."

13 El artículo 65 precisa el alcance del principio de igualdad en este terreno: "1. Todas las personas físicas o jurídicas que, en el sector público o en el privado, suministren bienes o servicios disponibles para el público, ofrecidos fuera del ámbito de la vida privada y familiar, estarán obligadas, en sus actividades y en las transacciones consiguientes, al cumplimiento del principio de igualdad de trato entre mujeres y hombres, evitando discriminaciones, directas o indirectas, por razón de sexo. 2. Lo previsto en el apartado anterior no afecta a la libertad de contratación, incluida la libertad de la persona de elegir a la otra parte contratante, siempre y cuando dicha elección no venga determinada por su sexon.

14 Se fomenta, en efecto, la participación de las mujeres en los consejos de administración de las sociedades mercantiles, incentivando una composición equilibrada de estos órganos, que se ha de alcanzar de forma progresiva: "Las sociedades obligadas a presentar cuenta de pérdidas y ganancias no abreviada procurarán incluir en su Consejo de administración un número de mujeres que permita alcanzar una presencia equilibrada entre mujeres y hombres en un plazo de ocho años a partir de la entrada en vigor de esta Ley. Lo previsto en el párrafo anterior se tendrá en cuenta para los nombrtamientos que se realicen a medida que venza el mandato de los consejeros designados antes de la entrada en vigor de esta Ley" (art. 71.1). A los efectos de esta Ley, "Se entenderá por composición equilibrada a presencia de mujeres y hombres de forma que, en el conjunto a que se refiera, las personas de cada sexo no superen el sesenta por ciento ni sean menos del cuarenta por ciento" (Disposición Adicional Primera).

15 La Ley define en su artículo 6 lo que ha de entenderse por discriminación directa ("situación en que se encuentra una persona que sea, haya sido o pudiera ser tratada, en atención a su sexo, de manera menos favorable que otra en situación comparable.) e indirecta ("la situación en que una disposición, criterio o práctica aparentemente neutros pone a personas de un sexo en desventaja particular con respecto a personas del otro, salvo que dicha disposición, criterio o prácti- 
los Trabajadores (en concreto su art. 2.4) para incluir expresamente, dentro de la garantía de la dignidad e intimidad del trabajador, la protección frente al acoso por razón de origen racial o étnico, religión o convicciones, discapacidad, edad u orientación sexual, y frente al acoso sexual y al acoso por razón de sexo.

En cuanto a las consecuencias jurídicas de las conductas discriminatorias, el anteproyecto no hace distinciones: "Los actos y las cláusulas de los negocios jurídicos que constituyan o causen discriminación por razón de sexo se considerarán nulos y sin efecto, y darán lugar a responsabilidad a través de un sistema de reparaciones o indemnizaciones que sean reales, efectivas $y$ proporcionadas al perjuicio sufrido (art. 10). Son nulas, por tanto, las decisiones discriminatorias de los empresarios.

\section{I.2. PROHIBICIÓN DE DETERMINADOS MOTIVOS DE DISCRIMINACIÓN}

Así como la mayoría de la doctrina coincide en que el principio de igualdad ante la ley es un mandato que se dirige a los poderes públicos, y muy particularmente al legislador, los autores que se han ocupado del alcance de esta prohibición constitucional tienden a pensar que la lucha contra la discriminación no debe detenerse en el frente legislativo. Si se parte del convencimiento de que la discriminación es un fenómeno social antes que jurídico, es evidente que no basta con desterrar la discriminación legal, eliminando cualquier vestigio de discriminación en las normas del ordenamiento estatal. Porque no estamos ante episodios aislados de tratamiento desigual, sino ante una práctica sistemática, generalizada, que muchas veces no viene impuesta por una norma jurídica sino que es el resultado de una patrón o pauta de conducta social implícita, de estereotipos muy arraigados, como el de la inferioridad de la mujer o de ciertas etnias. Hay que combatir, por tanto, la discriminación social, los usos o conductas discriminatorias privadas que tengan una proyección social, y resulten, por ello, intolerables. De poco sirve acabar con la discriminación ante la ley o con la imputable en general a los poderes públicos si no se consiguen erradicar las diversas formas de segregación social, si no se ataca la raiz del problema, que es el prejuicio social.

ca puedan justificarse objetivamente en atención a una finalidad legítima y que los medios para alcanzar dicha finalidad sean necesarios y adecuados). En este último sentido, se dice expresamente que "no constituirá discriminación en el acceso al empleo... una diferencia de trato basada en una característica relacionada con el sexo cuando, debido a la naturaleza de las actividades profesionales concretas o al contexto en el que se lleven a cabo, dicha característica constituya un requisito profesional esencial y determinante, siempre y cuando el objetivo sea legítimo y el requisito proporcionado" (art. 5). En todo caso, la tutela antidiscriminatoria comprende la garantía de indemnidad frente a las eventuales consecuencias negativas que pudiera padecer una persona como reacción a la presentación por su parte "de queja, reclamación, denuncia, demanda o recurso, de cualquier tipo, destinados a impedir su discriminación y a exigir el cumplimiento efectivo del principio de igualdad de trato entre mujeres y bombres" (art. 9). 
En la noción de discriminación (toda distinción, exclusión o restricción contra determinados sujetos que la sufren como víctimas) encontramos un plus que se añade a la simple diferencia de trato no razonable. Y ese plus es su carácter peyorativo y vejatorio y el trasfondo del rechazo y la estigmatización de un grupo social, generalmente marginado o vulnerable, al que se impide o dificulta de hecho el pleno ejercicio de sus derechos por sus características innatas o adquiridas, al margen de los méritos o comportamientos individuales. Es la propia dignidad del ser humano la que se ve afectada, porque quienes integran estos grupos son tratados no como personas diferentes sino como seres inferiores, que no merecen el mismo respeto. Se les relega a la condición de ciudadanos de segunda. El motivo de la distinción es algo más que irrazonable, es odioso, y de ningún modo puede aceptarse porque resulta humillante para quienes sufren esa marginación.

De ahí que el Tribunal Constitucional admitiera en su Sentencia 108/1989, de 8 de junio, antes citada, que la autonomía de los sujetos privados sí está limitada "por la probibición de incurrir en discriminaciones contrarias al orden público constitucional, como son, entre otras, las que expresamente se indican en el art. 14 CE. Lo cierto es que la contundencia de la fórmula constitucional ("sin que pueda prevalecer...") no autoriza a excluir sin más de su ámbito de aplicación las prácticas discriminatorias privadas.

A la misma conclusión se llega si acudimos a los convenios internacionales suscritos por España en esta materia. Todos estos documentos tienen un punto en común: los Estados que los ratifican no sólo se responsabilizan del cumplimiento por sus propios órganos de la prohibición de no discriminar, sino que adquieren el compromiso de adoptar las medidas adecuadas para evitar que otros discriminen. A la obligación de respetar lo dispuesto en los textos internacionales, no cometiendo directamente actos discriminatorios, se añade siempre la obligación de prevenir y sancionar debidamente las conductas discriminatorias de terceros en cualquier escenario de la vida social, poniendo a disposición de las víctimas los cauces procesales más idóneos para reparar la violación ${ }^{16}$.

16 Sirva como botón de muestra la Convención sobre la eliminación de todas las formas de discriminación contra la mujer de 1979, ratificada por España en 1983. Los Estados Partes, conscientes de que la discriminación contra la mujer dificulta la participación de la mujer, en las mismas condiciones que el bombre, en la vida política, social, económica y cultural de su país, se comprometen a adoptar las medidas necesarias a fin de suprimir esta discriminación en todas sus formas y manifestaciones. Esta concepción omnicomprensiva se refleja en la definición contenida en su art. 1: la expresión discriminación contra la mujer denotará toda distinción, exclusión o restricción basada en el sexo que tenga por objeto o por resultado menoscabar o anular el reconocimiento, goce o ejercicio por la mujer, independientemente de su estado civil, sobre la base de la igualdad del hombre y la mujer, de los derechos bumanos y las libertades fundamentales en las esferas política, económica, social, cultural y civil o en cualquier otra esfera. Para combatir esta lacra, los Estados no sólo se comprometen a abstenerse de incurrir en todo acto o práctica discriminatoria y garantizar la protección efectiva de la mujer contra todo acto de discriminación, sino también a tomar todas las medidas apropiadas para eliminar la discriminación contra la mujer practicada por cualesquiera personas, organizaciones o empresas (art. 2.e). Medidas destinadas, 
Para un sector de la doctrina, la vinculación de los particulares al principio de no discriminación sería mediata y exigiría una previa intervención del legislador, encargado de concretar el alcance del principio en cada uno de los ámbitos o escenarios regidos por el Derecho privado, o del correspondiente órgano judicial, que está obligado a interpretar de acuerdo con la Constitución una serie de conceptos jurídicos indeterminados, como el de orden público o el de buenas costumbres, que juegan un importante papel como límites de la libertad negocial.

Frente a esta postura, otros autores entienden que no es necesaria la interposición del legislador para apreciar la ineficacia de las regulaciones privadas discriminatorias. La expresa prohibición del art. 14 funcionaría como un límite externo de la libertad negocial que puede determinar la invalidez de las normas, actos o negocios jurídicos (contratos, estatutos de asociaciones, testamentos...) que infrinjan dicha prohibición.

Si adoptamos este último punto de vista, esto es, si entendemos que la Constitución atribuye al individuo un derecho fundamental a no ser discriminado $^{17}$, que despliega su eficacia, en mayor o menor medida, con todas las modulaciones que se quiera, frente a todos, cualquier pretensión de este tipo, fundada directamente en el art. $14 \mathrm{CE}$, y dirigida contra un particular, tendría que ser examinada por nuestros tribunales en clave constitucional. El órgano judicial se enfrenta en estos casos a un problema de difícil resolución: el conflicto entre el principio de no discriminación y la exigencia de respeto a la autonomía privada. Si ante ese dilema el órgano judicial llega a la conclusión de que en ese supuesto debe prevalecer la regla del art. 14, nada le impedirá proteger a la víctima, ordenando el cese de la conducta discriminatoria y la correspondiente reparación, en su caso.

¿Cuáles son los factores que ha de tener en cuenta el juez al hacer esa ponderación? Fundamentalmente, tres. En primer lugar, la repercusión social de la discriminación, la existencia de un patrón de conducta generalizado o bastante extendido, desde un punto de vista sociológico. No es lo mismo un acto o negocio jurídico aislado, como la decisión de arrendar una vivienda, que la aplicación sistemática de unos códigos discriminatorios por parte de colegios o guarderías privadas, de agencias inmobiliarias, de entidades aseguradoras, de la banca privada (a la hora de conceder créditos, por ejemplo), o de los empresarios a la hora de contratar trabajadores. Cuando concurre esta circunstancia, la

por ejemplo, a modificar los patrones socio-culturales de conducta de hombres y mujeres, con miras a alcanzar la eliminación de los prejuicios y las prácticas consuetudinarias y de cualquier otra indole que estén basados en la idea de la inferioridad o superioridad de cualquiera de los sexos o en funciones estereotipadas de hombres y mujeres (art. 5.a). Tanto en la esfera de la educación (art. 10), como en la del empleo (art. 11) o en otros ámbitos como la vida económica (se alude expresamente al derecho a obtener préstamos bancarios y créditos financieros) y cultural (lo que comprendería el derecho a participar en actividades de esparcimiento), el tráfico jurídico (art. 15) o las relaciones familiares (art. 16).

17 Véase, por ejemplo, REY MARTINEZ, F.: El derecho fundamental a no ser discriminado por razón de sexo, Madrid, McGraw-Hill, 1995. 
decisión discriminatoria deja de ser un asunto estrictamente privado y pasa a ser un asunto de relevancia pública ${ }^{18}$.

En este sentido, podría resultar útil la solución adoptada en el ordenamiento norteamericano, que siempre ha distinguido dos esferas dentro del sector privado: una relacionada con el acceso a bienes y servicios de interés público, socialmente relevantes, y otra que comprende las actividades propiamente privadas, carentes de esa proyección pública. En la primera de ellas, se admite la operatividad de las disposiciones legales antidiscriminatorias y así, los poderes públicos pueden prohibir (y han prohibido de hecho) la discriminación en el ámbito de la vivienda, la educación, el empleo o los establecimientos públicos ${ }^{19}$. En la esfera estrictamente privada, en cambio, no se permite al Estado legislar al amparo de la equal protection clause. La Civil Rights Act de 1964, que dedica su Título II a garantizar la no discriminación o segregación en el disfrute de los bienes y servicios públicos (y muy particularmente, en el acceso a los establecimientos públicos), exceptúa expresamente del ámbito de aplicación de la ley el caso de los clubes privados u otros establecimientos no abiertos al público ${ }^{20}$.

En segundo lugar, es un dato decisivo la posición dominante o monopolística de la entidad discriminadora en el mercado o la sociedad. Con arreglo a este criterio, el único club recreativo, la única sala de cine o la única piscina abierta al público en una determinada localidad no podría excluir a determi-

18 Véase ALONSO GARCÍA, E.: "El principio de igualdad del artículo 14 de la CE", $R A P$, n. ${ }^{\circ}$ 100-102, 1983, pp. 83 y ss; y La interpretación de la Constitución, CEC, Madrid, 1984, pp. 563-564.

19 Ultimamente, se han denunciado algunos casos de discriminación practicada por compañías aéreas contra pasajeros de origen o aspecto árabe (a veces tras la denuncia de otros pasajeros que consideraban sospechoso su comportamiento). En un proceso seguido ante un juez federal de distrito de Los Angeles, que terminó con la estimación de la demanda presentada por la ACLU, el argumento esgrimido por la compañía United Airlines era que incluso en el caso de que la alegación de discriminación fuese cierta, los tribunales federales no podían intervenir. Pues bien, el mensaje que mediante esta decisión se trasmite a las compañías es que no están exentas de obligación de respetar los derechos civiles (y más concretamente, el Título VI de Ley de Derechos Civiles de 1964). En opinión del juez, la discrecionalidad del personal de la compañía a la hora de determinar quién puede volar no confiere a estos empleados una licencia para discriminar en función de particulares prejuicios. En diciembre de 2001, Assem Bayaa fue expulsado de un avión de United Airlines que iba a volar de Los Angeles a N. York, pese a haber pasado numerosos controles de seguridad antes de embarcar. Se le expulsó porque su presencia creaba un clima incómodo. Tras su desalojo no fue objeto de ninguna indagación, interrogatorio, registro o control adicional por el personal de seguridad. De hecho, se le ofreció inmediatamente un pasaje para el siguiente vuelo. La exclusión no estuvo motivada, pues, por razones relacionadas con la seguridad. En este caso, como en otros similares, el personal actuó inducido por el prejuicio irracional de otro pasajero, basado en la simple apariencia del expulsado. Como advierte la ACLU, el combate contra el terrorismo no lo justifica todo. Están en juego valores fundamentales que costó mucho conquistar. La discriminación no puede tolerarse como si fuese un mal menor, porque es una experiencia humillante para quien la sufre.

20 La línea divisoria entre actividades con relevancia pública y actividades estrictamente ("distinctly") privadas no siempre está clara. A título de ejemplo, los tribunales federales se han planteado en varias ocasiones si las consultas privadas de los dentistas son "places of public accommodation en orden a la aplicación de las normas que prohíben la discriminación de los pacientes (o clientes) que son seropositivos, esto es, que tienen anticuerpos del virus VIH. 
nadas categorías de personas por motivos de raza, sexo o creencias religiosas. Una cosa es acotar un espacio de libertad en el que priman las preferencias y simpatías personales y otra abusar de una posición de virtual monopolio para discriminar a quienes no tienen otra alternativa y no pueden acudir a otro establecimiento en la zona que ofrezca ese mismo servicio.

Y el tercer factor a valorar es el de la posible afectación del núcleo esencial de la dignidad o integridad moral de la persona discriminada. Para Alfaro, que considera ilícita la discriminación que resulta contraria a la dignidad del discriminado, una de las circunstancias que hacen más probable la existencia de una vejación es precisamente el carácter público y notorio de la misma, porque sólo en ese caso puede producirse el efecto deseado por el discriminador: "producir status para el grupo del discriminador mediante la vejación del miembro del otro grupo social, ${ }^{21}$.

Fuera de estos supuestos, "la protección de la intimidad y de la libertad individual obligan a aceptar que los particulares pueden ser arbitrarios (y discriminatorios) en la selección de sus co-contratantes y en la regulación de sus relaciones con ellos e-igualmente—que no tengan por qué justificar sus decisiones $^{22}$.

\section{LA PROYECCIÓN EN EL ÁMBITO CIVIL}

La incidencia de la Constitución de 1978, en general, y del principio de igualdad y no discriminación, en particular, en el Derecho Civil es indiscutible. En el texto constitucional se establecen ya algunos principios que, además de

21 ALFARO, J. (op. cit. pp. 78-79 y 106-114) cree que para resolver este tipo de controversias se ha de acudir no a la cláusula del art. 1255 del Código Civil, que es la utilizada habitualmente por la doctrina y la jurisprudencia, sino a la del art. 7.2 del mismo texto legal, que prohíbe el abuso de derecho o ejercicio antisocial del mismo. A su juicio, el único derecho fundamental de la persona rechazada que puede verse afectado por una negativa a contratar es su derecho a no ser sometido a un tratamiento vejatorio o degradante por parte de otro particular. En nuestro ordenamiento, supone "un ejercicio anticonstitucional del derecho a (no) contratar la negativa a contratar que signifique tratar vejatoriamente a otro particular, tratarle como si no fuera un ser bumano", porque el afectado no puede recuperar dicha dignidad dirigiéndose a otro competidor. Para este autor, el fundamento de la obligación de contratar en estos casos no es el carácter vinculante del principio de igualdad y no la discriminación en las relaciones inter privatos. Una negativa a contratar no es ilícita por ser discriminatoria, sino por atentar contra la dignidad de otro particular. Es éste el parámetro al que hay que acudir para valorar la legitimidad de la diferencia de trato. Las discriminaciones que no sean vejatorias, concluye Alfaro, son perfectamente lícitas. Siempre que exista competencia en el mercado (una alternativa razonablemente disponible para obtener el bien o servicio denegado) o medie el consentimiento inequívoco del discriminado (volenti no fit iniuria), que puede limitar o renunciar voluntariamente a sus derechos si obtiene, como compensación, determinadas contrapartidas. VIEIRA DE ANDRADE (op. cit. pp. 295 y ss), que coincide en la necesidad de prohibir únicamente las discriminaciones que afecten de manera intolerable a la dignidad humana de las víctimas, entiende que la libertad individual es también "el derecho a ser diferente, incongruente, irracional, ilógico, volubles.

22 ALFARO, J., op. cit., p. 63. 
presidir la regulación por el legislador de áreas concretas de este sector del ordenamiento, son susceptibles, entre tanto, de aplicación directa.

En materia de filiación, por ejemplo, el artículo $39.2 \mathrm{CE}$ consagra el principio de igualdad entre hijos legítimos e ilegítimos, una especificación de la regla general del artículo $14 \mathrm{CE}$ en el campo del Derecho de familia. Pues bien, como el propio Tribunal ha señalado, se trata de un principio directamente aplicable desde el momento de la entrada en vigor de la Constitución, antes incluso de la aprobación de la Ley 11/1981, de 13 de mayo, de modificación parcial del Código Civil ${ }^{23}$.

En este ámbito, la jurisprudencia relativa a la sucesión en los títulos nobiliarios puede servir como piedra de toque a la hora de medir el impacto de la regla constitucional de igualdad y no discriminación. El Tribunal Constitucional se ocupó de esta controvertida cuestión en la Sentencia 27/1982, de 24 de mayo. El recurso de amparo se dirigía en ese caso contra una Sentencia del Tribunal Supremo que había resuelto un litigio que enfrentaba a dos aspirantes a un título nobiliario. Lo que se discutía entonces era si la condición de casar con persona noble para poder adquirir un título nobiliario (condición prevista en la Real Orden por la que se creó dicho título) era o no contraria al artículo 14 de la Constitución. La STC 27/1982 hace algunas consideraciones previas sobre los títulos nobiliarios ("una de tantas supervivencias feudales). La Constitución de 1978 pudo prohibirlos (como hizo, por ejemplo, la Constitución italiana de 1947), pero de hecho existen, y algunos son incluso de nueva creación (rehabilitación). Así pues, poseer uno de estos títulos es un "hecho admitido por el ordenamiento jurídico actual.24.

El problema consiste en determinar las consecuencias jurídicas de este hecho. En principio, la posesión de un título nobiliario es simplemente un "honom, cuyo contenido "se agota en el derecho a adquirirlo, a usarlo y a protegerlo frente a terceros. No es, en ningún caso, "un signo definitorio de un sta$t u s$, como lo fue en el pasado. Esto no significa, sin embargo, que este hecho

23 Véase, en relación con los derechos hereditarios de los hijos extramatrimoniales, la STC 155/1987, de 14 de octubre. A la misma conclusión había llegado la Sala 1. ${ }^{a}$ del Tribunal Supremo en su Sentencia de 10 de febrero de 1986: "el principio de igualdad ante la ley sin discriminación alguna por razón de nacimiento que proclama el artículo $14 \ldots$ rige desde la entrada en vigor de la Constitución... y... los preceptos del Código Civil que trataban desigualmente a los hijos matrimoniales y extramatrimoniales, por estar basados en principios discriminatorios por razón de origen, quedaron sin eficacia por imperativo de la disposición derogatoria $3 .^{a}$ de dicha Norma fundamental.... Véase asimismo la Sentencia de la misma Sala (Civil) de 26 de diciembre de 1990, sobre la inconstitucionalidad sobrevenida de los preceptos discriminatorios del Código Civil en materia de sucesión. En Alemania, varias disposiciones del BGB en materia de Derecho de familia fueron declaradas inconstitucionales en la década de los 50 por ser incompatibles con la igualdad de sexos garantizada por el art. 3.2 de la Ley Fundamental.

24 Según el art. 62.f) de la CE, el Rey puede conceder honores y distinciones "con arreglo a las leyes. Nótese que el constituyente no suprimió los títulos nobiliarios, pero tampoco garantizó su existencia frente al legislador: las Cortes Generales pueden transformarlos drásticamente (excluyendo su trasmisibilidad, por ejemplo) o incluso abolirlos (GARCÍA TORRES, J: "Sint ut sunt aut non sint: pequeña contribución jurídico-constitucional al novísimo Derecho nobiliario de creación judicial", REDC, n. ${ }^{\circ} 22,1988$, p. 235). 
sea "irrelevante" para el Derecho. Para los Magistrados del TC el requisito de casar con noble para heredar el correspondiente título no tiene por qué considerarse discriminatorio "pues a fin de cuentas son de la misma indole el becho condicionante y el condicionado y tan anacrónico y residual es aquél como éste, pero no siendo inconstitucional el título nobiliario no puede serlo supeditar su adquisición por vía sucesoria al becho de casar con noble..

El requisito en cuestión, se dice en la Sentencia, podría ser ilícito como condición para heredar. Pero "siendo un becho licito el ser noble, no puede tampoco considerarse vejatorio ni contrario a Derecho el que, con efectos $l i$ mitados a determinadas relaciones jurídico-privadas, se exija la prueba de que uno mismo es noble (por ejemplo, para ser miembro de un club o asociación deportiva privada) o de que lo es su cónyuge..... La condición de casar con noble habría de considerarse nula "si a ella se quisiera vincular el nacimiento o el ejercicio de un derecho público subjetivo", lo que no sucede en este caso, porque el título nobiliario ya no tiene naturaleza de "función pública" en el sentido del artículo 23.2 de la Constitución. No puede decirse, en consecuencia, que dicha estipulación sea contraria, por discriminatoria, al artículo 14 CE.

Por otro lado, y en relación también con las reglas que rigen las sucesiones nobiliarias, se ha planteado la cuestión de la posible incidencia del principio constitucional que prohíbe la discriminación por razón de $\operatorname{sexo}^{25}$. En las Sentencias del Tribunal Supremo (Sala 1. ${ }^{a}$ ) de 20 de junio y de 27 de julio de 1987 se consideró inconstitucional (inconstitucionalidad sobrevenida) el tradicional criterio de preferencia de los varones, a identidad de línea y grado, en el orden sucesorio ${ }^{26}$. Un giro jurisprudencial que desató en su momento las críticas de quienes reivindican el carácter institucional, específico, del Derecho nobiliario. Aunque no todos los tribunales inferiores la siguieron, parece que la línea marcada en estas Sentencias logró imponerse, a juzgar por las numerosas resoluciones favorables a las primogénitas que se dictaron desde el año 1987.

La doctrina no ha sido unánime a la hora de enjuiciar esta solución jurisprudencial. Para algunos autores, el Derecho nobiliario no puede sustraerse a la influencia de los principios constitucionales y no puede admitirse, por tanto, la postergación de la mujer en este terreno. Otros piensan, en cambio, que tra-

25 Se ha discutido también la hipotética vulneración del principio que prohíbe la discriminación entre hijos matrimoniales y extramatrimoniales (art. 39.2 CE.). En la STS (1. $\left.{ }^{a}\right)$ de 7 de julio de 1986, por ejemplo, se mantiene una postura favorable a la aplicación de este principio constitucional en el ámbito de las sucesiones nobiliarias. Según esta sentencia, la condición de ser hijo legítimo sería discriminatoria.

26 Esta regla tradicional (que se aplicaría salvo previsión expresa en contrario) no es otra que la establecida para la sucesión en los mayorazgos por las Leyes de Toro (1505), que regulan por primera vez esta institución. Desde entonces se sucede en los títulos nobiliarios con arreglo a los principios clásicos de primogenitura y masculinidad. Tanto la Diputación de la Grandeza como el Ministerio de Justicia (con competencias en materia de sucesiones y rehabilitaciones nobiliarias) han venido manteniendo la vigencia del orden sucesorio tradicional. En todo caso, "la derogación por inconstitucionalidad sobrevenida del principio de masculinidad no puede tener efecto retroactivo por no existir norma legal que lo autorice (art. 2.3 del CC) y conculcar tal pretensión el principio constitucional de seguridad jurídica, (STS de 28 de abril de 1989). 
tándose de títulos otorgados antes de la Constitución, debe respetarse la ley fundacional del mismo, que suele reconocer expresamente la preeminencia del varón ${ }^{27}$.

La cuestión acabó recalando en el Tribunal Constitucional, que en la controvertida Sentencia 126/1997, de 3 de julio, desestimó una cuestión de inconstitucionalidad sobre la vigencia del principio de preferencia del varón establecido en las normas preconstitucionales que regulan el orden de sucesión en los títulos nobiliarios. Para la mayoría del Tribunal, la legislación histórica aplicable a la sucesión regular en los títulos nobiliarios y, en particular, la regla de la preferencia del varón sobre la mujer en igualdad de línea y grado no es contraria al art. $14 \mathrm{CE}$. La Sentencia considera que el título de nobleza es hoy un símbolo desprovisto de cualquier contenido jurídico-material: "el ostentar un título nobiliario no supone en modo alguno un status o condición estamental y privilegiada, ni tampoco conlleva el ejercicio de función pública alguna. Su significado es meramente simbólico, lo que excluye la existencia de una posible discriminación al adquirirlo.

Los títulos nobiliarios se adquieren hoy por vía sucesoria tal y como son ("tal y como han sido configurados en el pasado bistórico al que precisamente hacen boy referencia). En realidad, se han adquirido siempre con arreglo al mismo orden sucesorio, de modo que el régimen legal de transmisión post mortem "ha constituido, a lo largo del tiempo, un elemento inberente al propio título de nobleza". Resultaría "paradójico" que pudiera adquirirse ahora por vía sucesoria no tal como es y ha sido históricamente, sino al amparo de criterios distintos. La mayoría de los Magistrados llega a la conclusión de que "admitida la constitucionalidad de los títulos nobiliarios por su naturaleza meramente bonorífica y la finalidad de mantener vivo el recuerdo bistórico al que deben su otorgamiento, no cabe entender que un determinado elemento de dicha institución-el régimen de su transmisión mortis causa - haya de apartarse de las determinaciones establecidas en la Real carta de concesión. La voluntad regia que ésta expresa no puede alterarse sin desvirtuar el origen y la naturaleza bistórica de la institución. En otros términos, el Derecho de nobles sería resistente frente a la prohibición constitucional de discriminación por razón de sexo por tratarse de un Derecho histórico, de escaso significado y, sobre todo, de estricto carácter privado $^{28}$.

De la tesis sostenida en la STC 126/1997 discreparon los Magistrados Viver Pi-Sunyer y Vives Antón, por un lado, y Cruz Villalón, por otro. En el Voto Particular formulado por este último, se constata que los títulos nobiliarios son hoy "una institución viva, por no decir pujante", que encuentra su asiento en

27 Véase el estudio de HERNÁNDEZ GIL, A., La preferencia del varón en la sucesión nobiliaria después de la Constitución, 1992.

28 Véanse, en este mismo sentido, los trabajos de GARCÍA TORRES, J: "Sint ut sunt aut non sint...", cit., pp. 223-236; y "Sint ut fuerunt: La sucesión nobiliaria en la STC de 3 de julio de 1997", REDC, n. ${ }^{\circ}$ 52, 1998, pp. 219-267. Para este autor, carece de sentido el empeño por modernizar o actualizar determinadas instituciones seculares. 
una facultad del monarca prevista en una Constitución que no quiso abolirlos. Desde 1978, se vienen concediendo, por medio de Reales Decretos debidamente refrendados, se viene sucediendo en la posesión de los mismos con la correspondiente intervención pública, se vienen rehabilitando y cediendo en vida, y sobre los mismos se viene pleiteando abundantemente. Todo esto es "derecho vigente, ius cogens en su inmensa mayoría, en absoluto derecho bistóricon. Es verdad, explica Cruz Villalón, que la posesión de un título nobiliario no determina una diferencia de status, pero es preciso reconocer que el título nobiliario es hoy un bien inmaterial, que se integra en el patrimonio de ciertos individuos y familias. Y el argumento de que una institución histórica no puede ser tocada en uno de sus elementos sin inmediatamente desnaturalizarla, sin hacerla irreconocible, no se sostiene. Con ello, "se postula para la institución una impermeabilidad a la bistoria absolutamente privilegiada. Para empezar, la preferencia del varón en el orden sucesorio no es "un elemento basilar de la institución", es un elemento "secundario" del sistema. Además, los títulos nobiliarios, como otras instituciones con raíces preconstitucionales, tienen que adaptarse también a la Constitución, al Estado de los derechos fundamentales. La cuestión no puede resolverse en nuestro ordenamiento como si se tratase de simples relaciones entre particulares. Entre nosotros, los títulos nobiliarios tienen "carácter oficial, en su ordenación participan los poderes públicos.

La postura adoptada por el Tribunal Constitucional significó un jarro de agua fría para los partidarios de una actualización en clave constitucional de las reglas que rigen la sucesión en los títulos nobiliarios. Ocho años después, los grupos parlamentarios han decidido tomar la iniciativa. En julio de 2005 tuvo entrada en el registro del Congreso la Proposición de Ley de igualdad del hombre y la mujer en el orden de sucesión de los títulos nobiliarios, presentada por los Grupos Socialista, Popular y Coalición Canaria ${ }^{29}$, que fue aprobada en octubre pasado (Ley 33/2006, de 30 de octubre).

De acuerdo con lo dispuesto en el artículo 1, "el bombre y la mujer tienen igual derecho a suceder en las Grandezas de España y títulos nobiliarios, sin que pueda preferirse a las personas por razón de su sexo en el orden regular de llamamientos". En consecuencia, "dejarán de surtir efectos jurídicos aquellas previsiones de la Real Carta de concesión del título que excluyan a la mujer de los llamamientos, o que prefieran al varón en igualdad de linea y de grado, o sólo de grado, en ausencia de preferencia de linea o que contradigan de cualquier modo el igual derecho a suceder del hombre y la mujer. (art. 2).

29 La Exposición de Motivos de esta propuesta legislativa, que contó con el respaldo de los grupos mayoritarios, se cierra con la siguiente reflexión: "El principio de plena igualdad entre hombres y mujeres debe proyectarse también sobre las funciones meramente representativas y simbólicas, cuando éstas son reconocidas y amparadas por las leyes. Los sucesivos poseedores de un título de nobleza perpetuo se limitan a mantener vivo el recuerdo de un momento de nuestro pasado histórico. Es justo que la presente Ley reconozca que las mujeres tienen el mismo derecho que los varones a realizar esta función de representar simbólicamente a aquél de sus antepasados que, por sus méritos excepcionales, mereció ser agraciado por el Rey". 


\section{LA PROHIBICIÓN DE DISCRIMINACIÓN EN EL ACCESO A LOS ESTABLECIMIENTOS ABIERTOS AL PÚBLICO}

\section{III.1. El DERECHO DE ADMISIÓN DE LOS TITULARES DE ESTABLECIMIENTOS ABIERTOS AL PÚBLICO}

De forma recurrente, los medios de comunicación se hacen eco de la existencia de prácticas discriminatorias en el acceso a determinados establecimientos abiertos al público ${ }^{30}$. Los propietarios de estos locales suelen invocar para justificar este tipo de comportamientos el derecho de admisión que les asiste. Pero los juristas no hemos prestado demasiada atención a esta cuestión y son muchas las dudas que nos asaltan en relación con el contenido y los límites de esta facultad, que anularía lógicamente el supuesto derecho a ser admitido del potencial cliente. Lo que late en el fondo de este debate es la creciente dificultad para trazar una línea divisoria nítida entre la esfera pública y la esfera privada. No son pocas las actividades que se sitúan en una zona gris, fronteriza, las conductas aparentemente privadas que tienen una trascendencia social. Y entonces la autonomía privada deja de ser un valor absoluto y puede ceder ante la necesidad de erradicar todas las formas de discriminación específicamente condenadas por el constituyente.

El Tribunal Constitucional reconoció implícitamente el derecho de admisión en su Sentencia 73/1985, de 14 de junio. En esta resolución, denegó el amparo solicitado por una persona a la que se le había impedido el acceso a un Casino de Juego, en aplicación del art. 31.1 del Reglamento de Casinos de Juego de 1979, que otorgaba al Director la facultad de prohibir la entrada a las salas de juego "a aquellas personas de las que consten datos que permitan suponer fundadamente que habrán de observar una conducta desordenada o cometer irregularidades en la práctica de los juegos", sin que el Casino esté obligado a declarar al visitante los motivos de la no admisión. Para el Tribunal, de este tipo de decisiones adoptadas por particulares, sobre la base de suposiciones fundadas, no cabe deducir una vulneración del principio constitucional de igualdad, ya que constituye una actividad protectora de los intereses de la propia entidad privada. Y afirmó, además, que "no puede predicarse de los ciudadanos un derecho ilimitado de libre acceso" a los casinos o establecimientos de análogas características. En la misma dirección apuntan algunas Sentencias del Tribunal Supremo ${ }^{31}$.

30 Centramos nuestra atención en las discriminaciones que se producen en el momento del acceso al local, aunque hay casos en los que la víctima ya se encuentra dentro del establecimiento y es expulsada, como ocurrió en octubre de 2002 en una discoteca de Barcelona: dos mujeres lesbianas fueron obligadas a abandonarla a los pocos minutos por orden expresa de la propietaria.

31 Véase, por ejemplo, la Sentencia de 21 de abril de 1994 de la Sala 3. ${ }^{a}$ del Tribunal Supremo, en relación con la prohibición de entrada en una sala de baile de Barcelona. 
¿Significa esto que, entre nosotros, se acepta forma incondicional el derecho de admisión? ¿Y si la persona afectada es de raza negra o un gitano? La cuestión puede parecer irrelevante a primera vista, pero ha adquirido una dimensión que va más allá de lo meramente anecdótico, a la vista del resurgimiento del racismo y la xenofobia en las sociedades europeas. Se multiplican las denuncias relativas a discriminaciones, más o menos encubiertas, en el control de acceso a las discotecas u otros lugares de esparcimiento y las dirigidas contra los propietarios o empleados de algunos bares que tienen por norma no atender ni servir a clientes pertenecientes a determinadas minorías raciales (inmigrantes de color o norteafricanos, casi siempre) o expulsar a personas de una determinada orientación sexual (homosexuales, lesbianas) ${ }^{32}$.

32 En cuanto a la discriminación por razón de sexo, es ilustrativa la sentencia de la Corte de Apelación inglesa en un curioso caso [Gill v. El Vino Co. Ltd. (1983) 1 Q.B. 425] relacionado no con el acceso pero sí con el modo de prestar el servicio a los clientes de un determinado establecimiento abierto al público. Las demandantes en este episodio judicial eran dos mujeres que habían entrado en un conocido wine bar de Fleet St. y habían pedido algo de beber en la barra. El barman se había negado a servirles porque era norma de la casa atender únicamente a las clientes que se sentaran en una de las mesas del local. En vista de ello, solicitaron de un Tribunal de la ciudad de Londres una resolución que declarara que los propietarios del bar habían infringido el art. 29 de la Ley sobre Discriminación Sexual de 1975. La citada Ley, que afirma en su art. 1 que una persona discrimina a una mujer de un modo relevante a los efectos de dicha Ley "si le trata de manera menos favorable que a un hombre en razón de su sexo", dispone en el art. 29 (1) que es ilícito que cualquier persona relacionada con la provisión (mediante pago o no) de bienes y servicios al público discrimine a una mujer que pretenda obtener o usar esos bienes o servicios, bien negándole u omitiendo deliberadamente la provisión de uno de ellos, o bien negándose a proporcionarle bienes o servicios de la misma calidad, de la misma manera y en los mismos términos que son habituales en cada caso en relación con los clientes varones. Entre los servicios que se señalan expresamente como ejemplo, la ley menciona el acceso o el uso de cualquier lugar abierto al público y los servicios de entretenimiento, recreo o refrigerio. La Sentencia, favorable a los demandados, fue recurrida ante la Corte de Apelación.

La Corte de apelación admitió el recurso. Según el Magistrado Eveleigh L.J., el juez a quo llegó a la conclusión de que en este caso no había discriminación, influenciado sobre todo por el precedente de Ministry of Defence v. Jeremiah [1983] Q.B. 87. En aquel caso, el Juez Brightman había dicho que, en su opinión, la privación de oportunidades o cualquier otra diferencia de trato debe llevar aparejada un perjuicio (detriment) para que pueda calificarse de discriminatoria. Seguramente el juez a quo entendió que no podía hablarse de un perjuicio para las demandantes por el hecho de que no se les sirviera en una determinada zona del bar y rechazó, por tanto, la existencia de una discriminación. Para Eveleigh, la referencia al perjuicio en la decisión del Juez Brightman estaba justificada porque era un supuesto de discriminación en el ámbito laboral, pero aquí la cuestión no es si las mujeres sufrieron algún daño, sino simplemente si fueron tratadas menos favorablemente que los clientes varones. En este caso, se les negó la oportunidad de beber su consumición donde los hombres bebían, la posibilidad de alternar con otras personas que estaban tomando una copa en una zona de ese mismo local, que tiene un atractivo especial, una zona muy popular porque ofrece una atmósfera única muy apreciada por los clientes. Puede que esto parezca una nimiedad (se ha invocado la máxima de minimis non curat lex: la ley no debe ocuparse de asuntos triviales), pero lo cierto es que hubo claramente un rechazo a prestar un servicio. ¿Puede catalogarse esa negativa como de minimis? Eso significaría admitir que las mujeres han sido tratadas de forma menos favorable, pero sólo muy ligeramente. Eveleigh cree que no puede evocarse la máxima romana en una situación en lo que se ha negado a las demandantes es justamente lo que el Parlamento quiso garantizar, a saber, la igualdad en el disfrute de los servicios. 
En muchos de estos supuestos la discriminación se funda en un motivo, la raza, expresamente vedado por el art. 14 de la Constitución, que prohíbe de manera rotunda, sometiéndolas a un estricto escrutinio judicial, las diferencias de trato fundadas en una serie de criterios, que se consideran sospechosos o especialmente odiosos. Este es un dato que hay que tener muy presente, porque el derecho de admisión no puede amparar, a nuestro juicio, una política sistemática de discriminación racial por parte de establecimientos abiertos al público, que deben cumplimentar una serie de requisitos para obtener la correspondiente licencia o autorización administrativa y están sometidos en muchos aspectos de su actividad a una detallada reglamentación. A diferencia de lo que ocurre, por ejemplo, con un club o una sociedad recreativa privada ${ }^{33}$, existe aquí una implicación, una responsabilidad de la Administración que impide la caracterización de estos establecimientos regentados por particulares como espacios estrictamente privados, aunque no exista una situación de monopolio o una posición dominante en el mercado. Apoyándose precisamente en la previa concesión de una licencia estatal para dispensar bebidas alcohólicas, los jueces norteamericanos han combatido eficazmente la segregación racial en este tipo de negocios ${ }^{34}$.

En una opinión a la que también se adhirió Sir R. Ormrod, el Magistrado Griffiths L.J. se mostró también de acuerdo con el fallo estimatorio. El Vino's, explica Griffiths, no es un bar normal. Se ha convertido en una institución única en Fleet Street. Se llena todos los días de periodistas y abogados que comentan las incidencias de la jornada. Si un hombre quiere tomar una copa en este bar, puede hacerlo en medio del gentío que se agolpa apretadamente en torno a la barra. Allí puede reunirse con sus amigos y enterarse de más un rumor o cotilleo interesante, especialmente si es periodista. O puede sentarse, si lo desea, en una de las dos mesas que hay a la derecha, junto a la puerta principal del local, o pasar a una pequeña smoking room que hay al fondo, que cuenta con unas cuantas mesas y sillas. Lo cierto es que la mayoría de los hombres prefiere permanecer junto a la barra. A las mujeres, sin embargo, no se les permite entrar en ese área. No hay duda, pues, de que se les niega un servicio que sí se ofrece a los hombres. La única pregunta que debemos hacernos, dice Griffiths, es si las demandantes han sido tratadas de forma menos favorable que los hombres. Y sólo cabe una respuesta a esta pregunta: por supuesto que sí (JACKSON, P.: O. Hood Phillips' Leading Cases in Constitutional and Administrative Law, 6. ${ }^{a}$ ed., London, Sweet \& Maxwell, 1988, pp. 217-219).

33 El Juzgado de Primera Instancia e Instrucción n. 3 de Irún (Guipúzcoa), en sentencia fechada el 24 de enero de 1998, desestimó la demanda formulada contra el Casino de Irún (una asociación recreativa-cultural) por una persona que había visto rechazada su solicitud de ingreso como socio de la entidad y en la que alegaba la violación de su derecho a no ser discriminado en el acceso a las dependencias del Casino abiertas al público en general. Al demandante le había sido prohibida por acuerdo unánime de la Junta Directiva la entrada a todas las dependencias e instalaciones (local social, biblioteca, bar, sala de juegos) cuyo uso se reservaba en principio a los socios, aunque en la práctica el acceso al vestíbulo, al bar y a la sala del bingo fuese libre. A la hora de determinar si la diferencia de trato estaba o no justificada, el Juez destacó el hecho de que el actor mantenía un litigio con el Casino y existía un clima de enfrentamiento, una circunstancia que no concurría en los demás ciudadanos a los que se venía permitiendo la entrada. Esa manifiesta enemistad con algunos miembros de la Junta Directiva estaba en el origen de la supuesta discriminación. En opinión del Juez, la finalidad de esa prohibición no era contraria a los valores constitucionales, habida cuenta de que el casino es una entidad privada y propietaria de sus instalaciones. Parece además una medida racional para evitar incidentes.

34 Me remito en este punto a mi monografía Los derechos fundamentales en la frontera entre lo público y lo privado (La noción de state action en la jurisprudencia norteamericana), Ma- 
Es evidente que cuando la negativa a prestar un servicio obedece a motivos raciales, la exclusión constituye una afrenta vejatoria, un agravio para todos los integrantes del colectivo discriminado, que hiere en lo más profundo su orgullo y su dignidad. No es fácil, sin embargo, probar la existencia de esas prácticas, porque la motivación discriminatoria no suele explicitarse. El portero de una discoteca aducirá normalmente como excusa que el local está ya abarrotado, que se celebra una fiesta privada o que es necesario ser socio.

La cuestión se complica cuando la diferencia de trato obedece a motivos distintos de los expresamente prohibidos por el art. 14 CE. En la selección que se efectúa a la entrada de algunos locales de moda, el factor determinante suele ser la apariencia física, el aspecto exterior (la forma de vestir, por ejemplo). Aunque la cuestión carezca de relevancia constitucional, es lícito preguntarse si puede ejercerse el derecho de admisión de una manera tan arbitraria o abusiva. Si lo que pretende el propietario es asegurar un ambiente "selecto", puede lograr ese objetivo incrementando el precio de la entrada (un criterio de selección objetivo, inobjetable en un sistema de libre mercado) o expulsando del local a quienes no se comporten debidamente, sin necesidad de recurrir a fórmulas humillantes de segregación social. Es más, para conseguir ese mismo resultado no hace falta rechazar abiertamente la presencia de estos clientes: basta con atenderles peor y más tarde, deliberadamente.

No hay que olvidar que quienes explotan este tipo de establecimientos (cafeterías, restaurantes, hoteles, etc.) dirigen su oferta al público en general, manifiestan su voluntad de contratar, en principio, con cualquiera que acepte sus precios y condiciones de venta. Aunque no exista propiamente una obligación de contratar, la apertura del local implica, al menos, la renuncia a seleccionar con criterios individuales su clientela ${ }^{35}$. Otra cosa son las condiciones que se pueden imponer con carácter general y que tienen un fundamento objetivo y razonable, como la advertencia formulada en carteles colocados a la entrada de muchos cines que prohíben el acceso a los espectadores que pretendan consumir dentro de la sala productos (bebidas y alimentos) adquiridos en el exterior $^{36}$.

drid, McGraw-Hill, 1997, pp. 127 y ss. La responsabilidad del Estado se sustentaría en la convicción de que al otorgar permisos o licencias, los poderes públicos asumen, de algún modo, una función de supervisión de la actividad privada. Esa licencia administrativa sería una prueba de la complicidad del Estado, que aparece así involucrado en esas concretas prácticas discriminatorias. En Garner v. Lousiana [368 US 157 (1961)], uno de los célebres sit-in-cases, la Corte Suprema norteamericana dio a entender que la concesión de una licencia a un restaurante hacía de él una instalación pública (public facility). Precisamente, la Constitución de Louisiana (art. 1.12) garantiza expresamente el derecho a no ser discriminado en relación con los servicios y espacios abiertos al público.

35 ALFARO, J., op.cit., p. 78.

36 En una Resolución de 5 de febrero de 1999, el Tribunal de Defensa de la Competencia consideró que esta práctica, que podía explicarse como una reacción normal de los operadores para aumentar sus ingresos, además de no ser abusiva o contraria a la libre competencia, estaba amparada por la reserva del derecho de admisión. 
¿Cómo se regula esta cuestión en el ordenamiento español? El Reglamento General de Policía de Espectáculos Públicos y Actividades Recreativas, aprobado por R.D. 2816/1982, aplicable a todos los establecimientos abiertos al público, dispone en su art. 59.1.e) que el público no podrá entrar en el recinto o local sin cumplir los requisitos a los que la Empresa tuviese condicionado el derecho de admisión, a través de su publicidad o mediante carteles, bien visibles, colocados en los lugares de acceso, haciendo constar claramente tales requisitos. No se establece, pues, ninguna limitación a la hora de fijar las condiciones de admisión. Es más, las empresas podrán requerir para imponer la observancia de estos criterios de admisión el auxilio de los Agentes de la Autoridad (art. 59.1). Lo único que se exige es la publicidad de las mismas, un requisito no se suele cumplir. La mayoría de estos establecimientos se limita a indicar simplemente que la empresa se reserva el derecho de admisión, sin especificar los criterios de selección.

En los últimos años, algunas leyes autonómicas han regulado el derecho de admisión de una forma más restrictiva ${ }^{37}$. La Ley vasca 4/1995, de espectáculos públicos y actividades recreativas, señala que este derecho se ejercerá, en todo caso, de conformidad con el principio de no discriminación, quedando excluida igualmente cualquier aplicación arbitraria o vejatoria (art. 21.d). Pero es la Ley 17/1997 de la Comunidad de Madrid, que regula esta misma materia, la que hace un especial hincapié en las condiciones de ejercicio del derecho de admisión. En el art. 24.2 de este texto se lee lo siguiente: Este derecho no podrá utilizarse para restringir el acceso de manera arbitraria o discriminatoria, ni situar al usuario en condiciones de inferioridad, indefensión o agravio comparativo. El derecho de admisión deberá tener por finalidad impedir el acceso de personas que se comporten de manera violenta, que pueden producir molestias al público o usuarios o puedan alterar el normal desarrollo del espectáculo o actividad. Una fórmula parecida se recoge en el art. 23 de la Ley 4/2003, de 26 de febrero, de la Generalitat Valenciana, de espectáculos públicos, actividades recreativas y establecimientos públicos ${ }^{38}$.

37 La Ley catalana 10/1990, de 15 de junio, sobre policía del espectáculo, actividades recreativas y establecimientos públicos dispuso en su art. 16 que corresponde al Gobierno de la Generalitat regular por decreto "las condiciones objetivas en que es posible ejercer el derecho de admisión", condiciones que "han de ser públicas y conocidas por lo que el derecho de acceso a los locales y establecimientos de pública concurrencia sometidos a esta Ley no puede ser negado de manera arbitraria o improcedente.

38 Los titulares de estos establecimientos podrán establecer condiciones de admisión, al margen de las previstas legal o reglamentariamente, pero deberán ser visadas y aprobadas por el órgano competente en esta materia de la Generalitat y figurar de forma fácilmente legible en lugar visible a la entrada, y en su caso en las taquillas y en todos los puntos de venta de entradas o localidades. También deberán figurar esas condiciones en la publicidad o propaganda del espectáculo o establecimiento (art. 23.3). En todo caso, el ejercicio del derecho de admisión no podrá implicar ningún tipo de discriminación (art. 23.4). Y el público tiene derecho a ser informado a la entrada sobre las condiciones de admisión y a no recibir un trato desconsiderado ni discriminatorio [art. 26.c)]. En el capítulo de infracciones graves (art. 46), se incluye como tal el ejercicio del derecho de admisión de forma arbitraria, discriminatoria, abusiva o contrario a lo que establece el art. 14 (n. $\left.{ }^{\circ} 9\right)$. 
En Andalucía, el Decreto 10/2003, de 28 de enero, por el que se aprueba, en cumplimiento de lo dispuesto en la Ley autonómica 13/1999, de 15 de diciembre, el Reglamento General de la admisión de personas en los establecimientos de espectáculos públicos y actividades recreativas, regula el derecho de admisión, que se define como aquel derecho que asiste a todos los consumidores y usuarios a ser admitidos, con carácter general y en las mismas condiciones, en todos los establecimientos públicos. El Reglamento prohíbe establecer condiciones específicas de admisión basadas en criterios arbitrarios de nacionalidad, racistas o sexistas, así como en cualquier otra condición dirigida a seleccionar clientelas en función de subjetivas apreciaciones sobre la apariencia física de las personas, en la discapacidad de las mismas o en otras prácticas similares.

En el Derecho comparado no faltan ejemplos de normas que prohíben la discriminación en este tipo de establecimientos. Así, la Ley federal para prevenir y eliminar la discriminación, aprobada por la Cámara de Diputados de México el 11 de junio de 2003, incluye dentro de las prácticas discriminatorias prohibidas la de impedir el acceso a cualquier servicio público o institución privada que preste servicios al público, así como limitar el acceso y libre desplazamiento en los espacios públicos (art. 9.XXII). En Argentina, Ley n. ${ }^{\circ}$ 13592, sancionada por el Congreso el 23 de agosto de 1988, fue modificada en abril de 1997 (Ley n. ${ }^{\circ} 24.782$ ) para incorporar un nuevo art. 4 del siguiente tenor: "Se declara la obligatoriedad de exhibir en el ingreso a los locales bailables, de recreación, salas de espectáculos, bares, restaurantes u otros de acceso público, en forma clara y visible, el texto del art. 16 de la Constitución Nacional, junto con el de la ley. En el mismo pie, añade el art. 5, deberá incluirse un recuadro con la siguiente leyenda: "Frente a cualquier acto discriminatorio puede recurrir a la autoridad policial y/o juzgado civil de turno, quienes tienen la obligación de tomar la denuncia. Al propietario o responsable de estos establecimientos de acceso público que no cumpliese estrictamente lo dispuesto en los preceptos anteriores se le impondrá una multa.

\section{III.2. LA TUTELA PENAL: LOS ARTíCUlOS 511 y 512 DEL CP.}

$\mathrm{Al}$ margen de la agravante genérica del art. 22.4 ("cometer el delito por motivos racistas, antisemitas u otra clase de discriminación referente a la ideología, religión o creencias de la víctima, la etnia, raza o nación a la que pertenezca, su sexo u orientación sexual, o la enfermedad o minusvalía que padezcar) el art. 511 del vigente Código Penal castiga con una pena de prisión y multa e inhabilitación especial para empleo o cargo público al "particular encargado de un servicio público que deniegue a una persona una prestación a la que tenga derecho por razón de su ideología, religión o creencias, su pertenencia a una etnia o raza, su origen nacional, su sexo, orientación sexual...”. Si traigo a colación este precepto es porque, a mi juicio, la conducta que se tipifica como delictiva no difiere tanto de la del dueño o encargado de 
un establecimiento público que se niega a servir a un cliente por esos mismos motivos.

En efecto, el art. 511 no castiga la negativa del médico de guardia de un hospital público a atender a un gitano o a un negro o la obstinación del funcionario que se niega a tramitar un expediente por motivos racistas, sino el comportamiento de un particular (no funcionario) encargado de un servicio público, con arreglo a alguna de las formas o modalidades de gestión privada o indirecta de un servicio de titularidad pública, que de forma expresa o encubierta deniega la prestación a la que se tiene derecho por algún motivo discriminatorio. Se está pensando, naturalmente, en los empleados de una empresa de transporte público a la que se ha adjudicado una línea regular en virtud de una concesión administrativa, de una empresa de suministro de gas, agua o electricidad, de una compañía de servicios telefónicos o de telecomunicaciones, o de una gasolinera.

Más dudas suscita la inclusión dentro de este tipo penal de las actividades privadas de interés público (que no son servicios públicos en sentido estricto) sometidas a un régimen especial de autorización o licencia administrativa. Me refiero a sectores intensamente regulados por la Administración, como el de las oficinas de farmacia, las entidades financieras o de seguros, los hoteles o el de quienes prestan el servicio de taxi.

En cualquier caso, muchas de estas conductas discriminatorias pueden quedar comprendidas dentro del ámbito de aplicación del art. $512 \mathrm{CP}$, que castiga con la pena de habilitación especial para el ejercicio de profesión, oficio, industria o comercio por un periodo de uno a cuatro años a "los que en el ejercicio de sus actividades profesionales o empresariales denegaren a una persona una prestación a la que tenga derecho por razón de su ideología, religión o creencias, su pertenencia a una etnia o raza, su origen nacional, su sexo, orientación sexual ..... Es una de las novedades del Código Penal de $1995^{39}$.

39 Preceptos equivalentes pueden encontrarse en otros ordenamientos. Así, el art. 225.2 del Código Penal francés sanciona con una pena de dos años de prisión y multa a quien se niegue a suministrar un bien o servicio si esa decisión se funda en alguno de los motivos discriminatorios contemplados en el art. 225.1 y a quienes supediten esa prestación a una condición discriminatoria. El art. 261 bis del Código Penal suizo castiga con prisión o multa a "quien deniega una prestación por el mismo ofrecida y destinada a la generalidad, a una persona o a un grupo de personas por razón de su raza, etnia o religión". En Noruega, el art. 349.a) del CP noruego sanciona con una multa o 6 meses de prisión a “toda persona que en una actividad de trabajo o análoga niegue a otra persona bienes o servicios en las mismas condiciones que las aplicadas a otras debido a su religión, raza, el color de su piel, o su origen nacional o étnico". En Brasil, la Ley n. ${ }^{\circ} 7.716$, de 5 de enero de 1989, que define los delitos que son el resultado de un prejuicio racial, prevé una pena de reclusión de 1 a 3 años por "rechazar o impedir el acceso a un establecimiento comercial, negándose a servir, atender o recibir a un cliente o compradom (art. 5). La misma pena se impone a quien impida el acceso o rehúse atender en restaurantes, bares, discotecas o locales semejantes abiertos al público (art. 8), en establecimientos deportivos y clubes sociales o recreativos abiertos al público (art. 9), en peluquerías, termas o casas de masaje (art. 10). Y es también la sanción prevista por impedir el acceso a "las entradas sociales de edificios públicos o residencias y a los ascensores o escalera de acceso a los mismos" (art. 11) y a los transportes públicos, como aviones, barcos, autobuses, trenes, 
Hasta entonces, este tipo de discriminaciones, practicadas por particulares, o quedaban impunes o se castigaban en ocasiones como una falta de coacciones. Un elemento esencial de esta figura delictiva es la existencia de un derecho del particular a una prestación, un derecho que no puede confundirse con la genérica libertad para adquirir un producto o contratar un servicio.

Para M. ${ }^{a}$ Dolores Machado ${ }^{40}$, no sería punible la negativa de un particular a alquilar o vender un inmueble o la negativa a atender a un cliente en un bar o en un establecimiento comercial, porque no existe, en rigor, un derecho a la prestación que se deniega (como mucho, una expectativa), pudiendo seleccionar su clientela de acuerdo con las reglas del libre mercado siempre que no se atente contra la dignidad del agraviado. Sí lo sería, en cambio, la denegación de cualquier prestación por parte de quien desarrolla una actividad profesional o empresarial destinada al público en general, porque en ese caso la prestación sí constituye un derecho. Así, no sería una conducta típica la denegación de servicios por parte de un abogado que se niega a aceptar como cliente a alguien (salvo en el turno de oficio), pero sí la negativa de un taxista a prestar un servicio de transporte o de una farmacia a servir a un gitano, puesto que el art. 103 de la Ley General de Sanidad 14/1996, de 25 de abril, dispone que "las oficinas de farmacia son establecimientos sanitarios sujetos a planificación y obligados a dispensar al público en las condiciones previstas en la legislación medicamentos y especialidades farmaceuticass.

Si pasamos revista, sin ánimo de exhaustividad, a los repertorios jurisprudenciales correspondientes a los últimos años, nos encontramos con unas cuantas decisiones judiciales en las que se califica como falta de coacciones la negativa del dueño de un bar a servir a un inmigrante (la dictada en 1997 por el Juzgado de la localidad granadina de Iznallor, por ejemplo), o la expulsión de un árabe (Almería) o de una pareja de homosexuales (Gerona) de un bar ${ }^{41}$.

metro o cualquier otro medio (art. 12). La pena se agrava ligeramente (de 3 a 5 años de reclusión) cuando se niega el alojamiento en un hotel, pensión o establecimiento similar (art. 7).

40 La discriminación en el ámbito de los servicios públicos. Análisis del art. 511 CP. Tirant lo Blanch. Valencia. 2002, pp. 298 y ss.

41 En un caso en el que no estaba en juego la prohibición constitucional de discriminación, la Sentencia de la Audiencia Provincial de Tarragona (sección 3. ${ }^{\text {a) }}$ de 9 de abril de 1999, después de reconocer que "los propietarios o directivos de un centro destinado al uso público tienen el derecho a restringir el paso a particulares, derecho que se encuadra bajo la figura conocida usualmente como derecho de admisión", llega a la conclusión de que la retirada o anulación informática del pase de entrada temporal que portaba el denunciante por parte de los responsables del parque temático "Port Aventura" y la consiguiente prohibición de acceso al recinto estaba justificada al amparo del mencionado derecho, puesto que había hecho uso del pase de temporada en más de 60 ocasiones no con la finalidad de divertirse en sus instalaciones, sino para participar en concursos y obtener de forma habilidosa premios que luego vendía en tiendas de localidades cercanas, lo que resulta contrario a las reglas de la buena fe. Así pues, la decisión de los directivos del parque es perfectamente lícita, y no constituye ni delito ni falta de coacciones (entre otras cosas, porque de la prueba practicada no se desprende que se haya ejercido una vis síquica o compulsiva sobre el denunciante), sin perjuicio de que éste pueda reclamar la cantidad que corresponda por el pase que había pagado. 
El tipo del art. $512 \mathrm{CP}$ se aplicó por primera vez al dueño de un establecimiento de compraventa de coches de Murcia que se negó expresamente a atender a una persona de color ("yo no vendo a morenos como tú, ni a gitanos ni a morosi). En su Sentencia de 29 de septiembre de 1998, la Sala de lo Penal del Tribunal Supremo considera probado tanto el hecho de que el acusado se negó a tratar con el denunciante la venta de un vehiculo de los que ofrecía en venta en su local, como el dato subjetivo de que la negativa vino determinada por el deseo de discriminarle a causa de su pertenencia a una determinada etnia. Es justamente la concurrencia de este ánimo discriminatorio (dolo específico) lo que resulta dificil de acreditar en la mayoría de las ocasiones. La sentencia, que confirma la dictada en primera instancia por la Audiencia Provincial de Murcia, aclara que no se le condena por ser racista (porque el 512 no es un tipo penal de autor), sino por haber denegado en esa ocasión una determinada prestación a una persona que tenía derecho a ella.

Otra de las contadas resoluciones en las que se ha hecho aplicación del art. $512 \mathrm{CP}$ es la Sentencia de 11 de junio de 1999 de la Sección primera de la Audiencia Provincial de Alicante, por la que se condena, como autor del delito previsto en dicho precepto, al portero de un pub que en junio de 1996 impidió el acceso al local a dos personas de color y se le impone la pena de un año de inhabilitación especial para el ejercicio del oficio de portero en establecimientos públicos. En relación con los hechos, la Sentencia considera probado que el acusado impidió la entrada en el pub a dos ciudadanos de raza negra, precisamente por tal motivo, denegándoles asi un derecho concreto como es el acceso a un establecimiento público de esparcimiento. Tal prohibición de entrada $a$ limine consuma el delito, de modo que resulta ajeno al tipo el que posteriormente y tras la protesta de una de las acompañantes de los denunciantes se les permitiera el acceso.

La comunidad gitana también es víctima de este tipo de prácticas discriminatorias ${ }^{42}$. La Sentencia de la Audiencia Provincial de Valencia de 3 de junio de 2003 confirmó íntegramente la condena impuesta por el Juzgado de lo Penal n. ${ }^{\circ}$ 3 de esa misma ciudad al portero y el jefe de camareros de una discoteca por denegar a una persona de etnia gitana el acceso al local. La sentencia considera probado que la negativa no estuvo motivada por la indumentaria o el aspecto descuidado del denunciante o de sus amigos, ni por un supuesto estado de ebriedad. Todos ellos, de acuerdo con el testimonio de un policía que acudió al lugar de los hechos, iban correctamente vestidos y aseados y no estaban borrachos. La causa por la que no se le permitió la entrada fue única y exclusivamente su condición de gitano ${ }^{43}$.

42 Sobre la discriminación de la comunidad gitana en Europa, véase REY MARTINEZ, F.: "La prohibición de discriminación racial o étnica en la UE y en España: el caso de la minoría gitana", $R e-$ vista de Derecho Político, $n^{\circ}$ 57, 2003, pp. 63 y ss.

43 En FJ Tercero de esta Sentencia puede leerse lo siguiente: "Y poco importa que los recurrentes no se declaren xenófobos o racistas, pues lo que se reprime en el tipo penal aplicado son las actitudes de esa clase, y no cabe duda de que impedir a una persona la entrada a una discoteca 
En otras ocasiones, los particulares que deniegan la prestación son condenados como autores de una falta de vejaciones injustas (art. 620.2 CP). Así, en el asunto resuelto en apelación por la Sentencia de la Audiencia Provincial de Baleares de 30 de diciembre de 2000, los acusados, un camarero y el propietario del bar que se habían negado a servir a un grupo de discapacitados, fueron absueltos del delito tipificado en el art. 512 CP y condenados en su lugar por la comisión de la falta prevista en el art. $620.2 \mathrm{CP}^{44}$. Más recientemente, la Sentencia de la Audiencia Provincial de Castellón de 2 marzo de 2002 condenó como responsable de una falta de vejaciones injustas a la propietaria de un bar de Alcalá de Xivert que se negaba a servir bebidas a magrebíes. La causa tuvo su origen en la denuncia de un súbdito marroquí al que la acusada había invitado a abandonar el establecimiento ${ }^{45}$.

por su condición de gitano, sin otra causa objetiva quepudiese hacer entrar en juego el derecho de admisión, es una clara actitud racista que impide a otro el ejercicio pleno de su libertad, por lo que, estando absolutamente probado el hecho,... no cabe otra sentencia que la que viene dada, que debe ser confirmada..."

44 Los acusados habían sido condenados en primera instancia por el delito al que se ha hecho referencia a sendas penas de inhabilitación para el ejercicio del oficio de camarero en un establecimiento abierto al público o de cualquier iniciativa empresarial en el sector de la hostelería. En este caso, nadie ponía en duda el hecho de que se habían negado a servir a un numeroso grupo de discapacitados acompañados por algunos monitores, con la falsa excusa de que el establecimiento no estaba aún abierto. Pero el tribunal entiende que esa conducta no respondía a motivos xenófobos o discriminatorios (no se emplearon expresiones ofensivas o de desprecio), sino a razones de simple comodidad (resulta más difícil atender a estas personas que a los clientes normales). Pero una actitud así, aunque no tenga la entidad suficiente como para ser calificada de delictiva, no puede exculparse. Se trata de una conducta constitutiva de una vejación injusta de carácter leve.

45 El Juez Instructor había acordado el sobreseimiento provisional al entender, en contra del criterio expresado por el Ministerio Fiscal, que los hechos no tendrían encaje en la falta de vejaciones injustas, pudiendo constituir, de ser cierta la conducta imputada, un delito de los previstos en el art. 512 del CP. Pero el Instructor llega a la conclusión de que la actuación imputada a la dueña del establecimiento no aparece probada, basándose en el informe aportado por la Guardia Civil: $s i$ bien es cierto que existe un informe del Sargento de la Guardia Civil de Alcalá de Xivert, que relata que por observación directa únicamente los dueños no sirven a aquellos magrebies que no pagan las consumiciones o que protagonizan altercados o peleas con otros compatriotas suyos en el referido local, habiéndose observado que otros magrebies si acceden al bar e incluso consumen en el mismo, sin ningún tipo de impedimento o problema", no es menos cierto que existe una denuncia de la persona agraviada que ya por si solo... hubiere merecido el estudio del caso a través del juicio oral de acuerdo con el art. 962 de la LECrim. El Tribunal expresa algunas reservas iniciales respecto del informe, porque es de sentido común que la dueña, en presencia de la Guardia Civil, que está en "observación directa", no va a desarrollar ninguna actividad discriminatoria de corte xenófobo en el acceso a su establecimiento, por lo que tal informe no guarda demasiada aptitud conviccional. Y subraya el dato que existe otra denuncia contra la acusada, que tendría el mismo contenido xenófobo, lo que avalaría la tesis de que ésta podría guiarse por un hábito discriminatorio o excluyente hacia los magrebies. La Sala no puede reconducir de oficio los hechos al tipo del art. 512, pero en todo caso parece evidente que el denunciante ha sufrido un trato discriminatorio, innegablemente vejatorio, que por lo menos podría merecer la calificación de una falta ex art. 620.2 del CP. En la Sentencia, que estima el recurso de apelación interpuesto por el Ministerio Fiscal, queda muy claro que "el derecho de admisión en los establecimientos públicos ni es absoluto, ni puede amparar prácticas discriminatorias, pues la única finalidad que pudiere te- 


\section{III.3. LA PROTECCIÓN SUPRANACIONAL: EL COMITÉ DE LA ONU PARA LA ELIMINACIÓN DE LA DISCRIMINACIÓN RACIAL}

Para completar la sucinta aproximación al tratamiento que ha merecido esta cuestión en otros ordenamientos, voy a referirme a algunos casos planteados en los últimos años ante el Comité de las Naciones Unidas para la eliminación de la discriminación racial. Este Comité vela por la efectiva observancia de la Convención internacional sobre la eliminación de todas las formas de discriminación racial, adoptada en 1965 y en vigor desde enero de 1969. De acuerdo con lo dispuesto en su art. 5, los Estados Partes se comprometen a prohibir y eliminar la discriminación racial en todas sus formas y a garantizar en cualquier espacio de la vida social la igualdad en el goce de los derechos, incluyendo "el derecho de acceso a todos los lugares y servicios destinados al uso público, tales como los medios de transporte, boteles, restaurantes, cafés, espectáculos y parques" (letra f).

Antes de empezar, una precisión: los instrumentos internacionales de protección no permiten la interposición de demandas contra particulares porque sólo los Estados son parte y están directamente obligados. Lo que se somete a examen (una vez agotados los recursos en la jurisdicción interna) es la diligencia de las autoridades públicas a la hora de cumplir esas obligaciones contraidas $^{46}$, pero indirectamente se emite un juicio de valor sobre el comportamiento privado discriminatorio.

En la decisión de 10 de mayo de 2000 (demanda n. ${ }^{\circ}$ 17/1999 contra Dinamarca), el Comité estudia la denuncia presentada por un ingeniero danés de origen iraní que imputa a Dinamarca la violación de varios preceptos de la Convención. El 1 de febrero de 1997 el demandante fue a una discoteca en Odense, con su hermano y un grupo de amigos (dos de origen danés y cuatro no). El portero de la discoteca les negó la entrada. Cuando le preguntaron por qué motivo, el portero respondió que era por ser extranjeros. Al día siguiente, el demandante denunció el asunto a la policía como una conducta de discriminación

ner tan controvertido derecho sería el impedir el acceso a personas que desarrollaren una actividad violenta o inconveniente para el normal desarrollo de la actividad recreativa o de esparcimiento del establecimiento. En definitiva, el mero becho de mostrar un cartel indicativo de que se reserva el derecho de admisión, es algo inocuo pues tal derecho se ostenta sin hacer publicidad del mismo, como inherente al derecho de administración del establecimiento, siendo superficial el hacer publicidad de algo obvio.... Otra cosa será el establecimiento de unos requisitos de entrada o acceso a una determinada actividad recreativa o un concreto espectáculo público, en cuyo caso tales motivos de exclusión (nunca de carácter discriminatorio ni atentatorio contra derechos constitucionales) deberían de ser expresos y publicitados en el local, pero jamás un simple cartel de reserva del derecho de admisión puede dar cobertura a exclusiones inmotivadas de acceso al local, o a los servicios que se expenden en el mismo".

46 Muy especialmente, la obligación de garantizar a todas las personas que se hallen bajo su jurisdicción un recurso efectivo ante los tribunales nacionales competentes contra todo acto de discriminación racial prohibido por la Convención, así como el derecho a reclamar de esos tribunales una satisfacción o reparación justa y adecuada por el daño producido como consecuencia de la discriminación (art. 6). 
racial. El funcionario de policía de servicio no quiso aceptar la denuncia y se limitó a informarle de que la política de admisión de clientes competía exclusivamente a los propietarios de la discoteca. La denuncia por escrito presentada el 3 de febrero también fue rechazada por la policía. Apeló entonces al Fiscal del Estado, quien decidió iniciar una investigación. El Fiscal acabó planteando el caso ante el tribunal de distrito de Odense. En su decisión de 20 de marzo de 1998, el tribunal impuso al portero una multa de 1000 coronas danesas por violación del art. 1.2 de la Ley n. ${ }^{\circ} 626$ contra la discriminación racial, de 29 de septiembre de 1987.

El demandante había pedido al Fiscal que solicitara además una indemnización, de conformidad con la Ley danesa de responsabilidad civil, pero el tribunal entendió que la ofensa no tenía un carácter grave y humillante que justificara el pago de una indemnización y rechazó esa petición. Tampoco el Tribunal Superior del Distrito, que desestimó el recurso interpuesto por el denunciante, encontró fundamento para conceder la indemnización. En su resolución, este tribunal sostuvo que el portero había informado al grupo de buenas maneras que no podían entrar en la discoteca porque según las normas de ésta ya había más de diez extranjeros en ella. A su juicio, la multa impuesta al portero por el tribunal inferior era una condena suficiente, por lo que el demandante ya había obtenido satisfacción.

En su denuncia ante el Comité, el demandante invoca el art. 6 de la Convención, que dispone que se ha de garantizar una satisfacción o reparación justa y adecuada por cualquier daño derivado de discriminación racial. La multa puramente simbólica fijada por el tribunal no representa una satisfacción adecuada. Los Estados están obligados a garantizar la observancia efectiva de la Convención y las sanciones por incumplimiento deben ser efectivas. Al negarse a conceder una indemnización en aplicación de la legislación de responsabilidad civil, los tribunales daneses han incumplido el art. 2.1 de la Convención. Finalmente, al permitir que la discoteca denegase el acceso por motivos raciales, el Estado Parte habría incumplido las obligaciones contraidas en el art. 5.f) de esa misma Convención.

Para el Estado demandado (Dinamarca), no se habría producido ninguna violación de la Convención. La aprobación de la Ley n. ${ }^{\circ} 626$, que prohíbe la discriminación por motivos raciales, debe interpretarse como el cumplimiento de las obligaciones que emanan de los mencionados preceptos de la Convención. Además, las autoridades danesas han aplicado esas disposiciones penales en este caso concreto, sancionando al portero como responsable de un acto discriminatorio ${ }^{47}$.

47 En cuanto al argumento de que la multa no constituye una reparación efectiva, la representación del Estado denunciado afirma que la Convención no exige una forma concreta de sanción (la prisión, por ejemplo) o una pena de una severidad o duración determinadas. Las violaciones del art. 1 de Ley danesa se sancionan con "multa, arresto o prisión por un periodo que no exceda de 6 meses. La determinación de la sanción adecuada en cada caso queda dentro del margen de apreciación del Estado Parte. Son las autoridades nacionales las que están en mejores 
¿Cuál es la opinión del Comité en este caso? Por un lado, considera que la condena por un acto delictivo y el pago de una indemnización a la víctima son sanciones con funciones y objetivos distintos. Y admite que la víctima no siempre tiene el derecho a una indemnización económica que se añada a la sanción penal. Pero por otro, no duda en calificar la denegación del acceso a un lugar público por motivos de raza o nacionalidad de "experiencia bumillante, cuya justa reparación puede exigir algo más que la simple imposición de una sanción penal al autor. Aunque el Comité considera que los hechos descritos en la demanda no revelan ninguna infracción del art. 6, recomienda que Dinamarca adopte las medidas necesarias para garantizar que las reclamaciones de las víctimas de discriminación racial que pidan un satisfacción adecuada, incluida la indemnización económica, se examinen teniendo en cuenta los casos en los que la discriminación no ha entrañado daños corporales sino humillaciones o sufrimientos similares.

La demanda que dio pie a la decisión de 15 de marzo de 2002 (la 20/2000) se dirige también contra Dinamarca. El 20 de agosto de 1999, por la noche, la demandante (una ciudadana brasileña nacida y residente en Dinamarca), su hermano (súbdito danés de origen brasileño) y un amigo brasileño negro, se disponían a entrar en un restaurante, en el centro de Copenhague. El portero les dijo que no les podía dejar entrar porque había demasiada gente dentro. Decidieron esperar un rato delante del local. Cuando poco después un grupo de 7 u 8 personas salieron del restaurante, no se les dijo que entraran. Más tarde, siendo ellos los únicos que estaban aguardando, llegó un grupo de 5 o 6 daneses a los que se les permitió entrar inmediatamente. Entonces el portero dijo a la demandante y sus acompañantes que no valía la pena que esperasen más tiempo. Dadas las circunstancias, optaron por marcharse.

El 16 de septiembre (25 días después), el Centro de Documentación y Asesoramiento sobre la Discriminación Racial de Copenhague, una institución

condiciones para evaluar cuál es sanción más apropiada o qué sanción es suficientemente disuasoria. La sanción impuesta al portero en este caso está de acuerdo con la jurisprudencia nacional en supuestos similares y no puede considerarse "simbólica". Respecto de la indemnización por daños, ciertamente se puede reclamar por quien ha sido objeto de discriminación, pero es el Estado Parte el que determina las normas sustantivas y procesales para otorgarla. El derecho a una satisfacción adecuada no es absoluto ni incondicional sino que está sujeto a limitaciones (se suele exigir, por ejemplo, que la víctima demuestre la existencia de esos daños). Los Estados disponen de un margen de apreciación al regularlo, siempre que las condiciones no desvirtúen su propia esencia. Además, el hecho de que la persona que ha cometido un acto discriminatorio sea procesada y condenada puede constituir en algunos casos una forma efectiva y adecuada de resarcimiento o desagravio. En el ordenamiento danés, a tenor de lo dispueto en el art. 26.1 de la Ley sobre responsabilidad por daños, cabe una indemnización pero siempre que el acto ilícito haya causado realmente un daño al honor o la reputación de la víctima, esto es, a la percepción que ésta tiene de su propia estima. Ese daño ha de ser culposo y revestir cierta gravedad. Y para determinar si procede la indemnización y su eventual cuantía debe tenerse en cuenta la entidad del daño, la naturaleza del acto y otras circunstancias. La decisión judicial de denegar la indemnización se basó en una valoración concreta de esas circunstancias. Los tribunales daneses consideraron que los daños al honor del denunciante no habían sido suficientemente graves o humillantes como para dar lugar a una indemnización. Así lo cree también el abogado del Estado danés. 
independiente especializada en estas cuestiones, presentó la correspondiente denuncia ante la policia danesa. El 10 de enero de 2000, la policía comunicó al Centro que había decidido no hacer más indagaciones porque consideraban que la denegación de la entrada pudo deberse a motivos distintos de la discriminación racial. De acuerdo con la información facilitada por la policía, el portero había sido interrogado, pero no recordaba nada y había declarado que el restaurante tenía por costumbre dar prioridad a sus clientes habituales. El 25 de enero, el Centro presentó una denuncia ante el fiscal de distrito de Copenhague en nombre de la demandante. Remitiéndose a una decisión anterior adoptada por Comité en el caso L.K. contra Holanda (n. ${ }^{\circ} 4 / 1991$ ), sostuvo que no podía considerarse satisfactoria la investigación que había hecho la policía. El 6 de marzo, el fiscal informó al Centro de que no veía ningún motivo para revocar la decisión de la policía. Lamentaba que no se hubiese informado antes a la policía del incidente y mencionaba que distintos empleados del restaurante habían ofrecido la misma explicación: que lo normal era dar prioridad a los clientes habituales. En un escrito posterior el fiscal insistió en que no había ningún indicio de discriminación racial.

El letrado de la demandante sostenía que Dinamarca, como Estado Parte, había infringido las obligaciones contraídas en varios preceptos de la Convención. Básicamente, la obligación de tomar medidas efectivas en relación con este tipo de incidentes, entre ellas, la investigación de los verdaderos motivos del trato dispensado a la demandante para determinar si hubo o no discriminación racial. En este caso, argumenta el letrado, no se hizo una investigación adecuada, porque el mero hecho de que los empleados del restaurante declarasen que no existió discriminación racial no da respuesta a la cuestion de si efectivamente se produjo o no y la policía no se molestó en hacer indagaciones acerca del origen étnico de los clientes habituales. Se da además la circunstancia de que es práctica habitual de la policía de Copenhague en supuestos análogos interrogar a los clientes, cosa que en este caso no se hizo.

De esta valoración discrepa lógicamente el abogado del Estado demandado. En su opinión, la investigación realizada cumplió plenamente los requisitos que exige la Convención tal y como se viene interpretando por el Comité. La policía de Copenhague interrogó exhaustivamente a todas las personas involucradas en el caso, salvo al amigo brasileño de la demandante, y ello a pesar de las dificultades suplementarias ocasionadas por el retraso en denunciar el incidente. Teniendo en cuenta las declaraciones coincidentes de tres empleados y la afirmación de la demandante de que esa noche el lugar estaba muy concurrido, puede decirse que la policía tomó las medidas necesarias para determinar si se había producido discriminación racial. De haberse dado parte del incidente de inmediato, la policía habría podido investigar si efectivamente las personas a las que se permitió entrar al restaurante eran clientes.

El Comité llega a la siguiente conclusión: "Habida cuenta de las circunstancias concretas del caso, la policía no pudo realizar una investigación completa y detallada al respecto. Por consiguiente, el Comité no dispone de elementos que le permitan deducir en el presente caso que el Estado Parte ha vio- 
lado las disposiciones del Pacto. No obstante, el Comité desea subrayar la importancia que concede al deber del Estado Parte... de mantenerse alerta, principalmente haciendo que la policía realice investigaciones rápidas y eficientes sobre las denuncias, y que todas las personas, nacionales y extranjeras, que se hallan bajo la jurisdicción del Estado Parte disfruten sin discriminación del derecho establecido en virtud del párrafo f) del art. 5".

Termino este apartado haciendo referencia a la decisión fechada el 9 de agosto de 2001, que resuelve la demanda presentada por un ciudadano eslovaco de origen romaní contra Eslovaquia, alegando violación de los arts 2 a 6 de la Convención. Los hechos que sirven de base a la demanda son los que siguen: el 24 de abril de 1997, el demandante, junto con otros romaníes, fue a tomar algo al restaurante de la estación central del ferrocarril de Kosice (Eslovaquia). Una camarera, que decía obedecer órdenes del dueño de no servir a los romaníes, les dijo que se marcharan. El demandante pidió hablar con el encargado, quien le explicó que no atendían a romaníes porque varios de ellos habían destruido algunos enseres del restaurante. Sólo estaba dispuesto a atender a romaníes educados. El 7 de mayo, el demandante presentó una denuncia ante la Fiscalía General de Bratislava y pidió que se realizara una indagación para determinar si se había cometido un delito. Entretanto, y al amparo de la Ley de protección del consumidor, acudió también a la Inspección de Comercio de Eslovaquia, que le contestó mediante una carta fechada el 12 de septiembre en la que le informaba de que había investigado la denuncia y había comprobado in situ que el restaurante había atendido debidamente a mujeres romaníes, sin que detectara ninguna irregularidad, y de que el dueño se había comprometido a no discriminar en lo sucesivo a clientes educados, aunque fueran romaníes ${ }^{48}$. Por resolución de 8 de abril de 1998, el Departamento de la Policía del Ferrocarril de Kosice informó de que había investigado el asunto sin encontrar indicios de delito. El recurso del demandante ante la fiscalía del condado no prosperó.

En la demanda, la presunta víctima, tras constatar la inexistencia en Eslovaquia de leyes penales que prohiban expresamente la discriminación racial en el acceso a los lugares públicos, explica que, como gitano, se ve expuesto en cualquier momento al criterio caprichoso del dueño, que puede decidir atenderle si lo juzga lo bastante educado o no. El demandante cree que él y sus amigos fueron objeto de discriminación por motivos de raza u origen étnico. Y que el Estado demandado ha incumplido las obligaciones que se derivan del art. 3 de la Convención. Al no remediar o sancionar la discriminación racial, el Estado Parte ha promovido de hecho dicha discriminación, violando asimismo el apdo c) del art. 4 de ese mismo texto. Además, el hecho de que se mantuviese arrendado al restaurante un espacio en la principal estación ferroviaria, que pertenece a una institución pública, constituye también una promoción de

48 Según el demandante, el hecho de que el restaurante atendiera posteriormente a otros romaníes en modo alguno corregiría la discriminación de que fue objeto. El que los derechos enunciados en la Convención se reconozcan a otros no resta importancia a la vulneración sufrida por el demandante, que no pierde por ello su condición de víctima. 
la discriminación por las autoridades públicas. El demandante reclama una indemnización por el trato humillante y degradante de que fue objeto y que Eslovaquia adopte disposiciones eficaces para que ese restaurante no siga practicando la discriminación racial y apruebe leyes que prohiban expresamente la discriminación racial en lugares o servicios destinados al uso público ${ }^{49}$.

En este caso, la Fiscalía Regional de Kosice estudió el asunto y después de examinar la documentación consideró que había indicios de un delito de incitación al odio nacional o racial (art. 198.a1 CP) en la conducta del encargado del restaurante. Pero llegó a la conclusión de que tal conducta no entrañaba un peligro suficiente para ser considerada delictiva. El Fiscal General no se mostró de acuerdo con el dictamen jurídico de la Fiscalía Regional y en una instrucción dirigida a esta última sostenía que estaba suficientemente justificada la sospecha de que el encargado había cometido un delito de instigación al odio racial y le instaba a que actuara en consecuencia. El 19 de abril de 2000, el Fiscal del Distrito de Kosice procesó al encargado y el 28 de abril el tribunal le declaró culpable del mencionado delito y le condenó a pagar una multa o a una pena de prisión de tres meses. Para el letrado del demandante, una reacción tan tardía no puede considerarse un recurso efectivo. Han tenido que transcurrir tres años y medio y ha tenido que presentarse la presente demanda para que las autoridades eslovacas encausaran al responsable. Este hecho por sí solo equivale a una violación del art. 6 de la Convención.

Para el Comité, el Estado eslovaco no cometió ninguna violación, dado que finalmente, aunque sea con retraso, se dictó una sentencia y se impuso una condena al autor de la discriminación. Pero "recomienda que el Estado Parte complete su legislación a fin de garantizar el derecho de acceso a los lugares públicos, de conformidad con el párrafo f) del art. 5 de la Convención, y sancione la denegación del acceso a esos lugares por motivos de discriminación raciab. El Comité recomienda igualmente que Eslovaquia "adopte las medidas necesarias para que el procedimiento de investigación de las violaciones no se prolongue indebidamente.

49 El Estado demandado sale al paso de las críticas relacionadas con la ausencia de legislación y las carencias del sistema de protección contra los actos de discriminación racial. El art. 12.2 de la Constitución eslovaca garantiza los derechos fundamentales de todas las personas sin discriminación. La tutela de esos derechos puede recabarse a través de procedimientos administrativos, civiles y penales. El denunciante podía haber presentado una reclamación ante el Ministerio de Economía y otros recursos. Tenía abierta también la vía civil (indemnización por daño moral) y el cauce de la Ley sobre protección del consumidor, cuyo art. 6 prohíbe explicitamente la discriminación por parte del vendedor (sanción administrativa). Una argumentación que no convence al Comité, que considera que los hechos denunciados eran de tal naturaleza que el único cauce de reparación adecuado era la vía penal.. 


\section{PROHIBICIÓN DE DISCRIMINACIÓN Y AUTONOMÍA ASOCIATIVA}

En consonancia con principio de libertad de asociación, la fuente primaria de regulación de la estructura, organización y actividad asociativas son las normas acordadas por los socios y, en primer lugar, los estatutos, un pacto "constituyente" que éstos aprueban o aceptan voluntariamente en el momento en que ingresan en una asociación ya constituida.

\section{IV.1. LA EXIGENCIA DE DEMOCRACIA INTERNA}

La autonomía estatutaria es de tal calado, que permite incluso que una asociación se dote de una organización no democrática. La exigencia constitucional de democracia interna (arts. 6, 7 y $36 \mathrm{CE}$ ), que se impone expresamente a una serie de entidades representativas, como los partidos políticos, los sindicatos, las asociaciones empresariales o los colegios profesionales, no debería proyectarse indiscriminadamente sobre todas las organizaciones de base asociativa, como hizo, de forma poco meditada a mi juicio, la Ley Orgánica 1/2002, de 22 de marzo, reguladora del derecho de asociación ${ }^{50}$. Las reglas y valores democráticos (principio mayoritario, sufragio universal, renovación periódica y carácter electivo de los cargos directivos, derechos de las minorías, participación y control de los órganos de dirección...) constituyen un principio estructural del Estado-aparato que no tiene por qué extenderse como regla inderogable a todas las actividades y organizaciones sociales.

La Constitución española no prohibe expresamente la existencia de asociaciones cuyo funcionamiento interno no se ajuste a los principios democráticos, que opten por una estructura cerrada o que adopten incluso esquemas abiertamente autoritarios, ya que el socio tiene siempre la posibilidad de abandonar el grupo cuando lo desee. El único límite constitucional es la prohibición de asociaciones secretas y de carácter paramilitar (art. 22.5 CE).

Imponer una estructura organizativa democrática a una logia masónica, cuyo funcionamiento es, por definición, rígidamente jerárquico, sería una medida "contra natura", incompatible seguramente con una interpretación amplia y no paternalista del principio constitucional del pluralismo (Ya puestos, ¿por qué no democratizar el funcionamiento de las órdenes religiosas?). Como recordaba recientemente P. Salvador Coderch, el ámbito de lo público se rige por la democracia y el de lo privado, por el principio general de libertad: "en un país libre, la democracia no tiene por qué llegar a todas partes, ${ }^{51}$.

50 En su art. 2.5: "La organización interna y el funcionamiento de las asociaciones deben ser democráticos, con pleno respeto al pluralismo. Véanse, a este respecto, las SSTC 137/1998, de 23 de julio, FJ 13; y 135/2006, de 27 de abril, FJ 5. Esta última trata de salvar la consitucionalidad del precepto interpretándolo como una excepción al principio general de libertad de autoorganización.

51 En la Introducción a "Asociaciones, derechos fundamentales y autonomía privada", coordinado por el propio P. SALVADOR CODERCH, Civitas, 1997, p. 15. 


\section{IV.2. ¿CABE OPONER UN DERECHO CONSTITUCIONAL A SER ADMITIDO EN UNA ASOCIACIÓN PRIVADA FRENTE A LAS DISPOSICIONES ESTATUTARIAS QUE EXCLUYEN EL INGRESO DE DETERMINADAS CATEGORÍAS DE PERSONAS?}

En el ordenamiento español no existe, en rigor, un derecho fundamental, deducible directamente del artículo 22 de la Constitución, a ser admitido en una asociación privada ya constituida, accionable ante la jurisdicción ordinaria por cualquier persona que deseando formar parte de la misma viera denegada su pretensión, porque su reconocimiento supondría una intromisión en la plena libertad de la asociación (de los miembros que ya la integran) para escoger a los nuevos socios, a las personas con quienes desean asociarse. La aplicación de las normas estatutarias que regulan los requisitos y los procedimientos de admisión corresponde, pues, a los órganos de la propia asociación y, en principio, sus decisiones no son susceptibles de revisión judicial ${ }^{52}$.

Dar carta de naturaleza a tal derecho (y a la correlativa obligación) significa, como advirtió en su día A. Pace ${ }^{53}$, otorgar un injustificado privilegio a la supuesta libertad de asociarse de los aspirantes, en perjuicio de la libertad de asociación de los socios originarios, a los que no les quedaría otra salida que el abandono del grupo. Una solución incompatible con el carácter privado y voluntario del vínculo asociativo.

La Corte Suprema norteamericana ha reconocido que la esencia de la libertad constitucional de asociación, cuya garantía se incluye dentro del ámbito de protección de la I Enmienda, es precisamente la libertad para seleccionar a los miembros. La libertad de asociación presupone la libertad de no asociarse con quien no se desea. Desde esta perspectiva, el derecho a excluir a otros por cualquier motivo es esencial para preservar la autonomía y el carácter o identidad propia de los diferentes grupos que se forman espontáneamente como resultado de la libre iniciativa de los individuos ${ }^{54}$.

52 Véase, más ampliamente, BILBAO UBILLOS, J. M.: Libertad de asociación y derechos de los socios, Secretariado de Publicaciones de la Universidad de Valladolid, 1997, pp. 22 y ss.

53 Commento all'art 18, en "Commentario della Costituzione", Rapporti civili: arts. 13-20, a cura di G. Branca, Zanichelli/Ed. del Foro Ital., Bologna-Roma, 1977, p. 223. Y también en "Problematica delle libertà costituzionali,, II, Parte speciale, 2. ${ }^{\text {a }}$ ediz., CEDAM, Padova, 1992, pp. 377-378.

54 Por las mismas razones, corresponde a los organizadores de una manifestación, y sólo a ellos, definir el mensaje que se va a trasmitir y ese mensaje no se puede alterar o desvirtuar por la intervención de personas ajenas a la entidad convocante. La asistencia a una manifestación carece de sentido si no hay una comunión con lo que se quiere expresar. No se convoca una manifestación para que acuda a ella todo aquel que tenga algo que decir o expresar y pase casualmente por allí La adhesión a la convocatoria es, en principio, libre, pero en determinadas circunstancias los organizadores pueden restringir la participación en el acto, les asiste una suerte de derecho de exclusión, para preservar justamente el genuino significado de la iniciativa. Si cualquier ciudadano pudiera sumarse libremente a una manifestación, quien convoca se vería expuesto al peligro de que la misma escape finalmente a su control y adquiera un sentido distinto, contrario incluso al fijado inicialmente por los promotores. De ahí precisamente la ilicitud de las "contramanifestaciones" que tratan de impedir o perturbar el desarrollo de una manifestación previamente convocada. A este respecto es bien ilustrativa la decisión de la Corte Suprema de Estados Unidos en el caso Hurley $v$. 
Sentadas estas premisas, estamos en condiciones de analizar la posible ilicitud constitucional de las cláusulas estatutarias que excluyen el ingreso de las mujeres como miembros de pleno derecho. La existencia de miles de asociaciones integradas exclusivamente por mujeres es una realidad que se acepta pacíficamente. Lo que de vez en cuando se convierte en noticia y en motivo de controversia es la existencia de asociaciones formadas únicamente por hombres.

Lo que nos preguntamos es si cabe admitir, en buena lógica constitucional, la impugnación judicial de la decisión de rechazar una solicitud de adhesión tanto si ésta se adopta en aplicación de una norma estatutaria como en el caso de que no exista una disposición expresa, pero sí indicios de discriminación de un determinado grupo o categoría de personas (las mujeres, en este caso). El conflicto está servido: por un lado, la prohibición de discriminación por razón

Irish-American Gay Group [515 U.S. 557 (1995)]. La organización recurrente, South Boston Allied War Veterans Council, una asociación sin ánimo de lucro formada por representantes de varios grupos de veteranos de guerra, estaba autorizada por la ciudad de Boston para organizar el desfile anual del Día de San Patricio (o Día de la Evacuación). En 1993, esta asociación negó un lugar en el acto al GLIB, una organización de gays, lesbianas y bisexuales creada precisamente con el propósito de participar, como tal grupo y con su propia pancarta, en dicho desfile y manifestar de ese modo el orgullo de sus miembros por sus orígenes irlandeses y su identidad declaradamente homosexual o bisexual. El GLIB y algunos de sus miembros a título particular presentaron una demanda ante los tribunales estatales, alegando que la denegación de su solicitud de participación había violado, entre otras normas, una ley estatal que prohibía la discriminación por motivos de orientación sexual en establecimientos y lugares abiertos al público. El tribunal de 1. ${ }^{a}$ instancia apreció la existencia de dicha violación y ordenó al Council la incorporación del GLIB al desfile. Este fallo fue confirmado por el Tribunal Supremo de Massachusetts. La Corte Suprema norteamericana, en una decisión unánime dictada el 19 de junio de 1995, llegó a la conclusión de que la aplicación por los tribunales de Massachusetts de la ley estatal en el sentido de obligar a los particulares que organizan un desfile a incluir entre los participantes a un grupo que pretende difundir un mensaje que los organizadores no desean trasmitir, viola la I Enmienda. Y más concretamente, la libertad de expresión y la libertad de asociación "expresiva" de los organizadores, porque afecta a la capacidad de una organización privada para presentar o divulgar su propio mensaje, aunque en este caso no fuese un mensaje claramente articulable. De aceptarse esa intromisión o interferencia, los organizadores podrán verse obligados a alterar su mensaje o promover otro que no es el suyo. Apoyándose en la I Enmienda, la Corte se distanció de la interpretación de los tribunales estatales, en virtud de la cual no sólo el desfile es un espacio abierto al público, sino que el propio mensaje de los organizadores sería accesible al público en general. De acuerdo con esta tesis, cualquier grupo de personas con un mensaje que trasmitir podría invocar el derecho a participar en la definición del mensaje de la entidad organizadora, de forma tal que el contenido de esa comunicación podría ser moldeado por todos. Los 9 jueces del Alto Tribunal tienen claro que el que decide trasmitir un mensaje goza de autonomía para escoger y controlar el contenido de ese mensaje. Cuando un individuo pretende usar el poder del Estado para forzar a una organización privada a admitirle como miembro y sus opiniones son diametralmente opuestas a las de los organizadores, los derechos de la I Enmienda en cuestión son los de la organización y sus miembros, no los del aspirante. En el mismo criterio se inspiró la decisión de la Juez federal Helen Gillmor en el caso PFLAG et al. v. City and County of Honolulu et al. En una resolución dictada el 3 de julio de 2003 desestimó la demanda presentada ante el tribunal federal de distrito por varios grupos de defensa de los derechos de los gays excluidos del desfile del "Día de la Familia" en Honolulu (Hawai), al considerar que era la Coalición Cristiana y no la ciudad la organizadora del desfile (la implicación del municipio colaborando en algunos aspectos organizativos no era sustancial), por lo que le asiste el derecho a denegar la solicitud de aquellos grupos cuyos postulados morales no coinciden con los suyos. 
de sexo; por otro, la autonomía asociativa, como ingrediente esencial de la libertad de asociación.

En el ordenamiento español, la jurisprudencia no nos sirve de gran ayuda. Podemos consignar en el orden civil una sentencia del Juzgado de Primera Instancia de Villena (Alicante), dictada en el año 1987, que anuló, por violación del art. 14 de la CE, una cláusula de los Estatutos de la Junta Central de las Fiestas de Moros y Cristianos de dicha localidad que impedía la participación de mujeres como socias de pleno derecho. El mismo problema podría suscitarse con la tradicional exclusión de la mujeres de buena parte de las sociedades gastronómicas, entidades que tienen un fuerte arraigo en el País Vasco ${ }^{55}$. No parece que la Constitución exija poner fin a estas formas tradicionales de camaradería masculina. Tampoco parece razonable poner fuera de la ley las asociaciones de hombres separados que defienden los intereses de estos colectivos en los casos de crisis conyugal. En el terreno político, la Constitución no proscribe ideologías políticas, por disparatadas que puedan parecernos, y caben dentro del marco constitucional los partidos de ideario rigurosamente machista, que lleven hasta ese extremo sus convicciones ${ }^{56}$.

En esta materia, la doctrina elaborada por los tribunales norteamericanos tiene un especial interés. No hace falta recordar que en la lucha contra todo tipo de discriminaciones el "liderazgo" del Derecho norteamericano está fuera de discusión. En los Estados Unidos, el tradicional respeto por la autonomía de las asociaciones voluntarias privadas hizo de éstas durante mucho tiempo un reducto inexpugnable. Eran muchos los clubes sociales que sólo admitían socios varones o blancos, por expresa disposición estatutaria ${ }^{57}$. Pero en la década de

55 A diferencia de lo que sucede en estas sociedades, compuestas únicamente por hombres, la cofradías sevillanas han ido admitiendo la presencia de mujeres en las procesiones de Semana Santa, aunque todavía hay algunas que no permiten que desfilen como "nazarenas". Mención aparte merece el Círculo del Liceo de Barcelona, el club privado más antiguo (fundado en 1847) y más selecto y prestigioso de la ciudad, ubicado en mismo edificio del teatro del Liceo, que conservaba tradición desde hacía 150 años de vetar el ingreso de mujeres como socias de pleno derecho. En febrero de 2001, la Junta directiva rechazó las solicitudes de ingreso presentadas por $10 \mathrm{mu}-$ jeres, entre ellas, la soprano Montserrat Caballé, pero decidió convocar una Junta General extraordinaria para someter a discusión la eventual modificación de las normas estatutarias que regulan admisión de nuevos socios (el art. 6 se refiere expresamente a "varones"). Semanas después, tras una tensa y tumultuosa asamblea de 8 horas de duración (la cuestión había generado una fuerte polémica y un verdadero cisma entre los socios), se aprobó con 429 votos a favor y 290 en contra la propuesta de la junta de gobierno de la entidad de poner fin a exclusividad masculina modificando los estatutos. Para ello hubo que recurrir a una fórmula de compromiso: para la admisión de mujeres se exige una mayoría reforzada de votos de los socios (2/3) en lugar de la mayoría simple. Esta batalla no se ha librado aún en muchos círculos y casinos españoles, que siguen excluyendo a las mujeres como socias, en algunos casos mediante una cláusula estatutaria expresa.

56 La garantía del pluralismo ideológico es, dicho sea de paso, un argumento nada desdeñable en contra de la imposición por ley de cuotas o porcentajes mínimos de candidatos de uno u otro sexo en las listas electorales.

57 Una fuerte repercusión mediática ha tenido el caso del Augusta National Golf Club, de Augusta (Georgia), que organiza el celebre Master de Augusta, uno de los torneos más prestigiosos del mundo. Las normas internas prohíben la inscripción como socias de las mujeres. Sólo se admite su 
los ochenta se desencadenó toda una ofensiva legislativa de los poderes estatales y locales que intentaba poner fin a esta situación de tolerancia, prohibiendo estas prácticas discriminatorias. En tres sentencias dictadas entre 1984 y 1988, la Corte Suprema confirmó la constitucionalidad de sendas disposiciones que obligaban a asociaciones integradas exclusivamente por hombres a admitir también a mujeres ${ }^{58}$.

De acuerdo con la doctrina de la Corte Suprema, la Constitución protege la autonomía asociativa frente a eventuales medidas antidiscriminatorias únicamente en dos supuestos: cuando se trate de una expressive association, creada con el objetivo primordial de defender ante la opinión pública una determinada posición política, ideológica o social y cuya autonomía es, por eso mismo, una garantía instrumental del derecho a la libertad de expresión ${ }^{59}$; o cuando el grupo en cuestión sea una intimate association, categoría que se caracteriza por el establecimiento de profundos vínculos y compromisos entre un número necesariamente reducido de personas que comparten aspectos íntimos de sus vidas. Fuera de estos casos, no hay razón para que la libertad de asociación deba prevalecer necesariamente.

La jurisprudencia norteamericana sigue siendo, sin embargo, vacilante. Y no sólo respecto de la discriminación que padecen aún las mujeres ${ }^{60}$. En los úl-

presencia en instalaciones sociales como cónyuge de un socio titular (que adquiere esa condición mediante un sistema de cooptación o invitación de los ya socios). Hasta el año 1975 se prohibía también el ingreso de socios negros. El club respondió a la petición de una organización feminista afirmando que la política de admisiones es un asunto interno, no se puede imponer desde fuera. A los hombres que integran este selecto club les gusta reunirse para hablar de sus cosas, igual que hay clubes y organizaciones exclusivamente femeninas. A pesar de las presiones (las feministas se manifestaron en los alrededores y algunas firmas dejaron de patrocinar el Master) el club mantuvo irreductible su tradicional política de admisión.

58 Las tres decisiones, adoptadas por unanimidad, son Roberts $v$. United States Jaycees [ 468 U.S. 609 (1984)], Board of Directors of Rotary International v. Rotary Club of Duarte [481 U.S. 537 (1987)] y New York State Club Association v. City of New York [487 U.S. 1 (1988)].

59 Hay que demostrar, en todo caso, la existencia de un nexo entre el motivo de la exclusión y el sistema de valores o creencias que define la organización. De ahí, por ejemplo, que una organización de defensora de los derechos civiles no esté obligada a aceptar en sus filas a un persona declaradamente racista, próxima al Ku-Kux-Klan, ni una asociación judía a una persona de convicciones antisemitas.

60 Sirvan como botón de muestra los conflictos creados por la exclusión de las mujeres de algunos capítulos locales de la Logia de los Elks (no todos, porque tanto los estatutos como los líderes nacionales de esta Orden son partidarios de una política de puertas abiertas). Los jueces no siempre aplican el mismo criterio. Así, en el año 2001 la reiterada negativa de una logia local de la ciudad de Rome (Nueva York) a admitir como miembro a una mujer no fue considerada inconstitucional. Y eso que desde la reforma de 1995 de la Constitución de Gran Logia Nacional de los Elks se permitía la incorporación de mujeres. La mujer rechazada había planteado una reclamación ante el Departamento Estatal de Derechos Humanos, que desestimó su demanda por discriminación sexual diciendo que la logia de Rome no estaba regida por la legislación de establecimientos públicos sino por la ley estatal que regula las entidades de beneficiencia, que no están sujetas a la prohibición de discriminación. Para formar parte de los Elks, el candidato debía tener 21 años, creer en Dios y ser avalado por un miembro en activo. Finalmente, la candidatura tenía que ser aprobada por dos tercios de los miembros presentes que emitan su voto. En marzo de 1999 la protagonista de este caso solicitó su inscripción, con el respaldo de diez miembros y su marido. Pero su candidatura 
timos años, por ejemplo, varios tribunales estatales han dictado sentencias contradictorias en relación con la exclusión de los homosexuales de los Boy Scouts. A decir verdad, algunos pronunciamientos de la Corte Suprema de California (en particular, su decisión de 23 de marzo de 1998 en el caso de Timothy Curran ${ }^{61}$ ), se inscriben en la línea defendida por un amplio y solvente sector de la doctrina de ese país.

Lo que proponen estos autores es el retorno a la doctrina tradicional, más acorde con los valores del pluralismo, la autodeterminación individual y la privacy. Parten de la convicción de que los ciudadanos deben disfrutar de una amplia libertad para mantener y explorar diferentes concepciones de la sociedad. Los poderes públicos no deben inmiscuirse en este terreno para promover una determinada ideología, para imponer puntos de vista oficiales que desplacen las distintas creencias y opiniones de los ciudadanos. Aunque la discriminación racial o sexual sea detestable, el derecho de los grupos a discriminar debería tutelarse en determinadas circunstancias, como medida profiláctica, para salvaguardar las libertades individuales.

Para este sector, la limitación de la autonomía de los grupos privados sólo se justifica, desde un punto de vista constitucional, cuando la pertenencia a una asociación incide directamente en la efectiva igualdad de oportunidades de los ciudadanos a la hora de acceder a una serie de bienes o servicios, o disfrutar de ciertas ventajas económicas, significativas y demostrables (la privación de concretas oportunidades económicas, por ejemplo, constituye un perjuicio objetivo y cuantificable). Pensemos en las asociaciones que, por el número de inscritos, por sus finalidades, o por su ámbito territorial de actuación, no pueden considerarse verdaderamente privadas. $\mathrm{O}$ en las que operan en un régimen de monopolio u oligopolio y, debido al poder que han adquirido, pueden influir de algún modo en la vida de otros, limitando sus oportunidades profesionales o culturales. En las asociaciones, en suma, que se encuentran en una "posición de dominion (STC 218/1988).

De vez en cuando los medios de comunicación se hacen de eco de los conflictos motivados por la negativa a admitir mujeres por parte de ciertas entidades, que siguen aplicando una política discriminatoria, incluso en aquellos supuestos en los que la exclusión del grupo lesiona gravemente los legítimos intereses económicos o profesionales de las aspirantes. Es el caso de la Comunidad de pescadores de El Palmar, en la Albufera, que venía negando a las mu-

fue rechazada en una votación por los miembros de la logia. Lo mismo ocurrió poco después con otras dos aspirantes. En esas mismas asambleas fueron admitidos todos los candidatos varones. Lo volvieron a intentar en agosto de 2000 y fueron rechazadas de nuevo por la asamblea.

61 La solicitud presentada por Curran para convertirse en ayudante de scoutmaster (jefe de sección de exploradores) fue rechazada por una organización local de los Boy Scouts de America, tras declarar públicamente que era homosexual. Tanto la Corte Suprema como los tribunales inferiores llegaron a la conclusión de que la política de admisión de los Boy Scouts, que siguen considerando la homosexualidad una conducta moralmente incorrecta, incompatible con el ideario de la organización, no entraba dentro de la categoría de establecimientos de negocios o abiertos al público a los que pueden aplicarse las leyes antidiscriminatorias. 
jeres la posibilidad de integrarse en ese colectivo y ganarse la vida como pescadoras. Esta Comunidad es una asociación de Derecho privado creada en el año 1238 para la explotación económica de la pesca en la Albufera valenciana, unos derechos de explotación en exclusiva que han sido reconocidos por el Ayuntamiento de Valencia. Esta asociación se ha venido rigiendo por normas consuetudinarias, que regulan entre otras cosas los requisitos para ingresar como miembro de la misma: el principal es el ser hijo de alguno de los pescadores que la integran, además de mayor de edad.

En julio de 1997, cinco mujeres, hijas de pescadores miembros de la Comunidad, solicitaron mediante requerimiento notarial su ingreso en la Comunidad, siendo rechazada su candidatura por la Junta Directiva de la asociación, al no reunir los requisitos exigidos, porque la candidatura no era individual y no venían avaladas por dos pescadores en activo (una simple excusa). Dicha inadmisión fue ratificada por la Junta de Capítulos. En marzo de 1998, las cinco mujeres interpusieron una demanda de protección jurisdiccional de los derechos fundamentales contra el acuerdo de la Junta Directiva alegando la vulneración del art. $14 \mathrm{CE}$ y pidiendo que se declarase su derecho a ser miembros de la asociación al igual que los hijos de los demás pescadores, que se adaptasen las normas de admisión a lo dispuesto en el art. $14 \mathrm{CE}$, que proscribe la discriminación por razón de sexo, y que se les indemnizara por los daños y perjuicios ocasionados.

El Juzgado de $1 .^{a}$ Instancia n. ${ }^{\circ} 1$ de Valencia, mediante Sentencia de 5 de octubre de 1998, estimó la demanda, al entender que la verdadera razón de la inadmisión de las demandantes fue la exclusión de las mujeres con arreglo a las normas consuetudinarias que rigen su funcionamiento interno y declaró el derecho de las actoras a ser miembros de pleno derecho de la Comunidad en las mismas condiciones que los hijos de los pescadores que ya lo eran, acordando la modificación de las normas de admisión para adecuarlas a las exigencias del art. $14 \mathrm{CE}$ y condenando a la Comunidad al pago de una indemnización.

Dicha sentencia fue recurrida en apelación ante la Audiencia Provincial de Valencia, que dictó el 24 de junio de 1999 sentencia desestimando el recurso y confirmando íntegramente la decisión de instancia. Para la Audiencia, había quedado acreditado que la costumbre era no admitir mujeres en la Comunidad, a pesar de que formalmente se habían rechazado las solicitudes apelando a supuestos defectos de forma en las candidaturas. Es cierto, concluye, que un aspecto del derecho fundamental de asociación (art. $22 \mathrm{CE}$ ) es el de la libre autoorganización de la asociación, pero no lo es menos que ello no significa que puedan adoptarse decisiones asociativas que resulten contrarias a la prohibición constitucional de discriminación por razón de sexo.

La Comunidad recurrió en casación, recayendo Sentencia desestimatoria de la Sala de lo Civil del Tribunal Supremo el 8 de febrero de 2001, con razonamientos semejantes a la de apelación. De los hechos probados dedujo el TS que lo que pretendían las solicitantes era poder pescar en la Albuferoa, esto es, trabajar. So pretexto de deficiencias formales en las solicitudes, no se admitió a las actoras por el único hecho de ser mujeres. Así pues, el factor determi- 
nante para la discriminación laboral en este caso ha sido el sexo, vulnerando así el art. 14 CE.

Agotada vía judicial, la Comunidad decidió interponer un recurso de amparo ante el Tribunal Constitucional contra las referidas sentencias, por violación de sus derechos de igualdad (art. 14) y asociación (art. 22). La recurrente alegaba que dichas resoluciones judiciales habían interpretado y aplicado de forma indebida el principio constitucional de igualdad, porque no se había acreditado la existencia y aplicación de normas de admisión que impidieran el acceso de las mujeres a la Comunidad (no fueron rechazadas por su condición de mujeres sino por incumplir requisitos de presentación de solicitudes). Por otra parte, el art. $14 \mathrm{CE}$, que garantiza la igualdad de los españoles ante la ley, sólo es oponible frente a los poderes públicos, de manera que la autonomía de la voluntad entre particulares sólo puede ser limitada si así lo dispone la propia Constitución o la ley, por lo que, a falta de precepto constitucional o legal que así lo haga, no puede ser restringido judicialmente aplicando el art. 14 CE. Según la Comunidad recurrente, las sentencias impugnadas habrían lesionado su derecho de asociación en su dimensión negativa, al obligarle a admitir cinco nuevas asociadas al margen de los procedimientos ordinarios de ingreso. La Comunidad es una asociación privada, cuya creación, organización y funcionamiento se rige por disposiciones de los propios asociados, pudiendo establecer los requisitos que consideren oportunos para poder formar parte de la misma y determinar si los aspirantes cumplen dichos requisitos.

La Sección 1. ${ }^{a}$ del Tribunal Constitucional inadmitió el recurso mediante Auto de 20 de septiembre de 2001. Al margen de causa de inadmisión alegada por el Fiscal (falta de agotamiento de la vía judicial), el Auto confirmó la inicial apreciación de carencia de contenido constitucional de la demanda de amparo. Las Sentencias impugnadas llegaron a la conclusión, en virtud de un razonamiento que no puede tacharse de ilógico o arbitrario, de que la Comunidad de Pescadores de "El Palmar" impedía a las mujeres su acceso como miembros de aquélla, lo que supone una discriminación por razón de sexo contraria al art. $14 \mathrm{CE}$, ya que la denegación de ingreso en dicha Comunidad implicaba que las candidatas excluidas no podían pescar en La Albufera, al ostentar los miembros de dicha asociación el derecho exclusivo a ejercer la actividad pesquera en ese dominio público. Además, en el caso de las cinco actoras se les discriminó de forma indirecta, al exigirles para su ingreso en la Comunidad requisitos formales que, pese a su apariencia neutra, eran un instrumento de discriminación por razón de sexo, al resultar acreditado que tales requisitos no se exigían, al menos con el mismo rigor, a los candidatos varones en igualdad de circunstancias.

En cuanto a la posible lesión de su derecho de asociación (art. 22 CE), es verdad, admite el Auto, que el derecho a asociarse conlleva la potestad autoorganizatoria, libre en principio de injerencias del poder público, pero «el ejercicio de esa potestad no puede suponer en ningún caso la lesión de derechos fundamentales de terceros". Por el contrario, "está sujeto tanto a límites establecidos directamente en la propia Constitución como a otros que puedan fi- 
jarse para proteger o preservar otros derechos fundamentales, valores o bienes constitucionalmente protegidos o intereses constitucionalmente relevantes. Como los límites previstos en el Código Penal. Ahora bien, «el primer límite intrínseco de este derecho lo marca el principio de legalidad, en cuya virtud los Estatutos sociales, como ejercicio de la potestad de autonomía, han de acomodarse no sólo a la Constitución, sino también a las Leyes que, respetando el contenido esencial de tal derecho lo desarrollen o lo regulen.

Aplicando esta doctrina al caso, el Tribunal afirma que "no puede ampararse en la autonomía de la voluntad de las asociaciones privadas una decisión como la enjuiciada en las sentencias recurridas en amparo, consistente en denegar u obstaculizar el ingreso a la Comunidad de Pescadores por razón de sexo, cuando esta Comunidad ocupa una posición privilegiada, al tener reconocida por el poder público la explotación económica en exclusiva de un dominio público, las aguas de la Albufera y su riqueza piscícola, de modo que sólo se puede ejercer la actividad pesquera en ese lugar si se es miembro de dicha Comunidad. Por consiguiente, el ingreso en la Comunidad de Pescadores de "El Palmar", en cuanto medio para el acceso al trabajo y al disfrute de una concesión administrativa, no puede regularse por normas o prácticas que, de forma directa o indirecta, discriminen a las mujeres" ${ }^{62}$.

En el otro extremo del espectro se situarían las asociaciones lúdicas o recreativas, cuya única pretensión es facilitar el esparcimiento de sus miembros. Uno puede asociarse con quien quiera para compartir su tiempo de ocio o para un objetivo trivial, siempre que la asociación no adquiera una relevancia pública. La regla se invierte cuando aparece implicado un poder público ${ }^{63}$.

62 Uno de los últimos baluartes de la tradicional exclusión de las mujeres ha sido la Filarmónica de Viena, una de las orquestas más prestigiosas del mundo, que ha estado formada tradicionalmente por músicos varones. Ninguna mujer había llegado a ser miembro de pleno derecho de esta orquesta. Aunque desde hace años había mujeres que tocaban con la orquesta, su nombre no figuraba en los programas oficiales y seguían privadas del derecho a votar en las reuniones convocadas con el fin de decidir la política de la orquesta respecto del calendario de conciertos, los directores y las grabaciones discográficas. En 1996, el máximo responsable de la orquesta, Werner Resl, anunció su intención de desmantelar gradualmente uno de los últimos bastiones machistas del país. Las fuertes críticas dirigidas contra la exclusión de las mujeres y el hecho de que en la actualidad sean mujeres la mayoría de los estudiantes de música en Austria llevaron a Resl y a sus colegas a plantearse la necesidad de un cambio.

63 Este mismo argumento fue utilizado por la Corte Suprema de Canadá en la sentencia dictada en marzo de 1996 en el caso "Gould v. Yukon Order of Pioneers" [(1996) 1 R.C.S]. La demandante, Madelaine Gould, solicitó en 1987 su ingreso como miembro de dicha Orden, una logia o agrupación fraternal fundada en 1894 y consagrada a actividades sociales, históricas y culturales dirigidas a promover el bienestar de sus miembros (hombres de buena reputación, residentes en el territorio del río Yukon) y rememorar acontecimientos pasados. De acuerdo con lo dispuesto en sus estatutos, la Orden de los Pioneros tiene como objetivos el progreso del territorio del Yukon, la mútua protección de sus miembros, la formación entre ellos de estrechos lazos de fraternidad, la preservación de las tradiciones y ceremonias o ritos secretos característicos de la fraternidad de Klondike, la conservación en sus registros de los nombres de todos los pioneros del Yukon, así como la recopilación, conservación y divulgación de los documentos y anécdotas relativas a la historia de este territorio. Estos documentos se ponen gratuitamente a disposición del público y de los archivos 
El legislador ha de tener en cuenta, pues, las características concretas de las asociaciones cuyo funcionamiento pretende regular y no prohibir con carácter general estas prácticas discriminatorias privadas, porque ello tendría un coste muy alto en términos de libertad (el remedio sería peor que la enfermedad). Esto es lo máximo que una sociedad libre puede hacer, lo que dicta el sentido común.

Esta solución es, a mi juicio, la única constitucionalmente adecuada. Sobre todo, si se conecta la libertad de asociación con el valor del pluralismo (art. 1.1 CE) y con la libertad de expresión, que comprende la libertad de disentir de las convicciones dominantes, sin límites materiales ni tabúes sustraidos al mercado

públicos. Sus miembros participan asimismo en desfiles públicos y en una reunión anual de pioneros. Tras ser denegada su solicitud de adhesión por su condición de mujer, como único motivo, Gould presentó una queja ante la Comisión de derechos de la persona de Yukon, alegando que el rechazo de su petición había constituido un acto de discriminación por razón de sexo con arreglo a lo previsto en la Ley sobre los derechos de la persona de Yukon. La Comisión consideró que en la medida en que se dedicaba a la conservación de documentos de la historia de Yukon, la Orden prestaba un servicio al público. Y llegó a la conclusión de que la decisión discriminatoria estaba prohibida por el art. 8a) de la Ley. A juicio de la Comisión, no se puede prestar adecuadamente ese servicio público si no se permite la participación activa de las mujeres como miembros. En un pasaje de la resolución se llega a afirmar que si la compilación histórica era obra exclusiva de hombres, se produciría una distorsión de la historia en beneficio del sexo masculino (?). La Corte Suprema del territorio del Yukon anuló la decisión de la Comisión en 1991 y el Tribunal de Apelación confirmó su fallo en 1993. Los dos tribunales estimaron que el hecho de rechazar a Gould como miembro, aun siendo un trato diferente, no constituía un acto discriminatorio en el sentido del art. 8a) de la Ley. La Corte Suprema de Canadá desestimó el recurso de apelación interpuesto por Gould y la Comisión. En la sentencia, la mayoría sostuvo que la política discriminatoria de la Orden consistente en admitir únicamente hombres como miembros no está prohibida por el citado art. 8. El legislador, en el apdo. c) de este precepto, prohíbe expresamente la discriminación en la pertenencia a ciertos tipos de organismos (la lista incluye los sindicatos y las asociaciones profesionales o comerciales), distinguiendo este supuesto del de la discriminación "relativa a la oferta o la prestación al público de servicios, bienes o instalaciones", prohibida en el apdo. a). Se trata de organismos cuya actuación resulta relevante en el ámbito de la economía. Es evidente que en ningún caso puede incluirse dentro de esa categoría la Orden de los Pioneros.

Por otra parte, el servicio que en este caso se ofrece al público no es la pertenencia a la asociación, sino el producto final de su actividad: encontrar, conservar y poner a disposición de todos esos documentos históricos. Y ese es un servicio que se ofrece sin discriminación alguna. Cualquier interesado puede consultar esos documentos, aunque la tarea de recopilación haya sido obra de hombres exclusivamente. Obligar a un organismo privado a orientar su actividad en una determinada dirección tendría graves repercusiones en la libertad de asociación y expresión de quienes se agrupan con ese objetivo. La Orden no pretende ofrecer una versión definitiva de la historia de Yukon. Quienes deseen presentar una visión diferente pueden hacerlo. En definitiva, la Orden no deforma o tergiversa la historia de Yukon por excluir a las mujeres. Además, la historia que se trata de conservar es sobre todo la historia de la propia Orden.

Es verdad que, bajo determinadas circunstancias, la pertenencia a una organización, en la medida en que proporciona ventajas u oportunidades, puede constituir efectivamente un servicio ofrecido al público, siendo necesario por ello un examen de la adecuación a la ley de la política de admisión de ese grupo. Pero no es este el caso. La Orden de los Pioneros está al servicio de sus propios miembros y de la preservación de una hermandad fundada en los valores morales (no importa si son valores pasados de moda o escasamente compartidos). Lo que proporciona a sus miembros es una asociación íntima, la ocasión de socializarse en un entorno exclusivamente masculino y en un clima de camaradería destinado a favorecer el desarrollo y enriquecimiento afectivo de sus miembros. Ese carácter casi familiar justifica una política de admisión selectiva. 
de las ideas. La libertad de asociación no está circunscrita a finalidades "políticamente correctas ${ }^{, 64}$. No podemos deslizarnos por la pendiente que conduce al establecimiento de un comité de salud o higiene ideológica, que borre del mapa a heterodoxos y excéntricos, que se resisten a asumir los patrones dominantes.

El pensador inglés I. Berlin ha rebatido en sus obras los argumentos de los críticos del liberalismo. Berlin insiste en sus escritos en que el valor del pluralismo está directamente asociado a los de libertad y tolerancia, mientras que el ideal "monista" de un sistema de valores compartidos por todos (una utopía uniformadora) está asociado históricamente al fanatismo, el dogmatismo y la tiranía. Si se parte de la idea de que un determinado valor o sistema de valores es el verdadero, el supremo, se tenderá a pensar que es legítimo imponer su vigencia en todos los ámbitos y por cualquier medio. Todo vale si se trata de realizar ese valor absoluto. Ningún precio será demasiado alto. El principio constitucional de igualdad es ciertamente un gran principio, pero no es el único sobre el que las personas pueden basar legítimamente su conducta. La Constitución prescribe los valores que el Estado ha de perseguir y respetar, pero las personas e instituciones privadas deben ser libres para actuar de acuerdo con múltiples y contradictorios valores e intereses, que no tienen por qué coincidir con los adoptados en la esfera pública ${ }^{65}$.

ABSTRACT. The Constitutional principle of equality is basic to our legal order and the legislator has to comply with it. This principle serves as criteria in order to assess the legality of decisions adopted by public authorities. The question is whether the principle of equality can affect ex Constitutione (thus, without the support of any legal act) on the decisions and rules adopted by private actors. The answer, of both legal literature and Constitutional Court's case-law, to that question can be summarized as follows: as general rule Spanish Constitution does not impose equal treatment on interactions between private actors. In these cases, private autonomy is the value to be primarily

64 Del mismo modo que la libertad de expresión se pone a prueba cuando ampara la difusión de mensajes que desagradan, que irritan, que resultan incómodos, políticamente incorrectos, y la libertad de disentir comprende la posibilidad de discrepar en asuntos importantes, sensibles, polémicos, la libertad de asociación adquiere pleno sentido cuando una serie de personas se asocian para difundir mejor esos mensajes o para finalidades que nos parecen extravagantes. Nuestra Constitución garantiza la libertad de pensamiento y la libertad de actuar con arreglo a las propias convicciones. Si creemos de verdad en el mercado de las ideas, debemos confiar también en el mercado de las asociaciones: si una asociación no me gusta, tengo siempre la posibilidad de constituir un grupo alternativo. Así funciona una sociedad pluralista: no se trata de uniformizar sino de convivir.

65 El Estado está obligado a promover en el ámbito de sus responsabilidades educativas los valores constitucionales (la igualdad de sexos, entre ellos). Pero el Derecho como instrumento de regulación, conformación y transformación de las relaciones sociales tiene sus límites, no es omnipotente. Nos hace libres, no virtuosos. 
protected. Personal freedom necessary implies freedom of choice, even if such a freedom is exercised in an irrational manner. This sphere of personal action lies beyond Constitutional rules, and therefore the principle of equality can only be imposed here by Parliamentary Act. Concerning the effects of the Constitutional principle of non-discrimination on specific grounds, one has to be aware that discrimination as such is more a social issue than a legal one. In fact, when we are confronted with consistent social practices of discrimination (i.e. women or certain races) legal acts are normally less efficient than public policies oriented to fight against the various and real causes of the problem. This conclusion is supported by the analysis of the International Agreements ratified on this matter by Spain. Moreover, within the notion of discrimination one can find an additional feature: when the intention is not only to treat differently but to reject, annoy or insult a concrete social group in order to restrain its members from a full exercise of several rights. In these cases, buman dignity is questioned since these persons are considered no so much as different bus as being of lower level. However, if we interpret that Constitution (art. 14) confers to every individual a fundamental right not to be discriminated in relation to any potential threat, national courts would have to examine these cases with due respect to what Constitution says. In these cases, three criteria can be suggested in order to solve the potential conflict between principle of non-discrimination and the need to protect private autonomy: social repercussion of a given discrimination, the dominnant or monopolistic position of the discriminatory entity either in market or society, and the possible constraints affecting the core of human dignity or moral integrity of the concerned individual. Taking account of the problematic issues described above, the author analyzes the possible effects of the Constitutional non-discrimination principle on three areas: first, within the civil law, the mortis causa succession of titles concerning nobility; second, access to buildings which are formally opened to public; and third, the conflict between non-discrimination and the autonomy to constitute private associations. The article concludes by arguing that pluralism must prevail over the idea of a single code of absolute values and the dictatorship of what is generally known as politically correct. 